\title{
The changing role of the health care customer: review, synthesis and research agenda
}

Janet R. McColl-Kennedy, Hannah Snyder, Mattias Elg, Lars Witell, Anu Helkkula, Suellen

J. Hogan and Laurel Anderson

\section{Journal Article}

\section{Tweet}

N.B.: When citing this work, cite the original article.

Original Publication:

Janet R. McColl-Kennedy, Hannah Snyder, Mattias Elg, Lars Witell, Anu Helkkula, Suellen J. Hogan and Laurel Anderson, The changing role of the health care customer: review, synthesis and research agenda, Journal of Service Management, 2017. 28(1).

http://dx.doi.org/10.1108/JOSM-01-2016-0018

Copyright: Emerald: 24 month embargo

http://www.emeraldinsight.com/

Postprint available at: Linköping University Electronic Press

http://urn.kb.se/resolve?urn=urn:nbn:se:liu:diva-137109

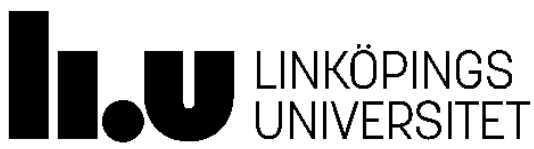


The Changing Role of the Health Care Customer: Review, Synthesis and Research Agenda

Janet R. McColl-Kennedy, PhD

UQ Business School, The University of Queensland, Australia

Email: j.mccoll-kennedy@business.uq.edu.au

Hannah Snyder, PhD

UQ Business School, The University of Queensland, Australia

Email: $\underline{\text { h.snyder@business.uq.edu.au }}$

Mattias Elg, PhD

Linköping University, Sweden

Email: mattias.elg@liu.se

Lars Witell, PhD

Linköping University, Sweden

Email: lars.witell@liu.se

Anu Helkkula, PhD

Hanken School of Economics, Finland

Email: anu.helkkula@hanken.fi

Suellen J. Hogan, PhD

UQ Business School, The University of Queensland, Australia

Email: s.hogan@business.uq.edu.au

Laurel Anderson, PhD

Arizona State University, USA

Email: laurel.anderson@asu.edu

Paper accepted at Journal of Service Management 17 August 2016

Doi 10.1108/JOSM-01-2016-0018 


\title{
The Changing Role of the Health Care Customer: Review, Synthesis and Research Agenda
}

\author{
Abstract \\ Purpose - The purpose of this study is to synthesize findings from health care research with \\ those in service research to identify key conceptualizations of the changing role of the health care \\ customer, to identify gaps in theory, and to propose a compelling research agenda. \\ Design/methodology/approach - This study combines a meta-narrative review of health care \\ research, and a systematic review of service research, using thematic analysis to identify key \\ practice approaches and the changing role of the health care customer. \\ Findings - The review reveals different conceptualizations of the customer role within the ten \\ key practice approaches, and identifies an increased activation of the role of health care customer \\ over time. This change implies a re-orientation, that is, moving away from the health care \\ professional setting the agenda, prescribing and delivering treatment where the customer merely \\ complies with orders, to the customer actively contributing and co-creating value with service \\ providers and other actors in the ecosystem to the extent the health care customer desires. \\ Originality/value - This study not only identifies key practice approaches by synthesizing \\ findings from health care research with those in service research, it identifies how the role of the \\ health care customer is changing and highlights effects of the changing role across the practice \\ approaches. A research agenda to guide future health care service research is also provided. \\ Key words - Role; Customer; Health care; Practices; Value Co-creation; Co-creation
}




\section{The Changing Role of the Health Care Customer: Review, Synthesis and Research Agenda}

"There has been an enormous change in the role of the patient... This shift to the patient in the center has been quite substantial and we can expect more... " [Dr Stener Kvinnsland, MD, PhD, physician, professor and entrepreneur. Keynote speaker at Frontiers in Service Conference 2016, Bergen, Norway.]

\section{Introduction}

Globally expenditure on health care is approaching \$6.5 trillion (Thomas et al., 2014). All developed economies face problems with increasing pressure on health care budgets due largely to an aging population, development of new treatments, technological advances that increase demand for treatment, and rising health care customer expectations. Clearly, health care services are not sustainable in their current form and operating models (World Health Organization, 2008). In addition, the nature of medical problems in the Western world is shifting from acute conditions to chronic and ongoing illnesses (Institute of Medicine, 2001), demanding revised models of health care service delivery both within hospitals and clinics, as well as in primary health care. An important question then is what is the role of the health care customer given these significant changes?

Traditionally, customers have been viewed as having a relatively passive role, essentially a recipient of what an organization does for them (Payne et al., 2008). This view has been prevalent in health care (Berry and Bendapudi, 2007; Lorig and Holman, 2003). But instead of viewing customers as passive, merely responding to market offerings, customers can be active in co-producing the service with health care professionals. In health care, this means that the customer (patient) can have a much more active role in their care by contributing a range of personal resources such as information and knowledge, and by engaging in a range of activities by themselves and with others to improve their health and well-being (McColl-Kennedy et al., 2012; Ostrom et al., 2015). 
In health care research, researchers have started to consider the passive role of the customer as limiting in the further development of health care (Hardyman et al., 2015). Attempts to redefine the roles of the health care customer have taken place through the introduction of different practice approaches, i.e., conceptualizations of the organizing frameworks that define roles, activities and associated interactions within health care. Accordingly, in health care research several practice approaches, such as Patient Participation (Roter, 1977), Self-Managed Care (Lorig and Holman, 2003) and Patient Centered Care (Epstein and Street 2011), have started to expand the role of the health care customer from passive to active with the customer being given greater responsibility for managing their own health.

In service research, Berry and Bendapudi (2007) identified health care as a "fertile field for service research" and provided a foundational platform to guide health care service research. They describe health care customers not only as being sick, in need of privacy and "whole person service”, but also at risk and reluctant. Health care related activities are not something that individuals approach willingly, but rather, it is something considered more of an obligation (MacGregor and Wathen, 2014). However, recent studies of health care customers provide important new insights into customer practices (McColl-Kennedy et al., 2012, 2016; Sweeney et al., 2015), the role of positivity for customer participation in health care service (Gallan et al., 2013), the importance of forms of messaging (Bone et al., 2009) and the dynamics of customer adherence to advice (Keller et al., 2011; Seiders et al., 2015). In addition, the introduction of eservices provides health care customers with greater access to knowledge and potentially fuller understanding of their illness and suggested activities that they can perform themselves to improve their health outcomes (Gummerus et al., 2004; Tian et al., 2014; Topol, 2015).

To date research on health care has been carried out largely along disciplinary lines, with little sharing of knowledge between medicine, nursing, and allied health on one hand and service 
research on the other. However, there is much to be gained from integrating findings from the disparate literatures. Here is where this paper contributes. The purpose is threefold: first, to synthesize findings from health care research with those in service research, identifying key conceptualizations of the changing role of the health care customer through key practice approaches; second, to examine the extant research and identify gaps in theory; and third, to propose a research agenda to guide future health care service research.

This paper contributes in at least four important ways. First, by taking a multidisciplinary approach, the research builds on and extends Berry and Bendapudi's (2007) foundational platform for health care service research, reviewing and synthesizing literature on the role of the health care customer from health care with that from service research and identifying "what we know". Specifically, the paper identifies how the role of the health care customer is conceptualized across key practice approaches, noting the core elements, disciplinary origins, overall contributions and illustrative references. Second, established effects of the changing role of health care customers in the key practice approaches are highlighted. Third, discussion centers on what service research can contribute to health care and what service research can learn from health care. Fourth, a research agenda on "what we still need to know", highlighting seven important areas of inquiry that emerged from the review and synthesis with suggested research questions designed to guide future research, is provided.

\section{Review and Synthesis Methodology}

In this study, conceptual and empirical articles published in health care research (medicine, nursing, and allied health professions), and service research (including marketing, consumer behavior and operations management) were analyzed. In order to assess and provide a synthesis of the literature on customer roles in health care, two commonly used approaches were combined. First, given that health care research is a very large research field with many sub-fields such as 
medicine, nursing, and allied health, a meta-narrative review approach is used (Wong et al., 2013). This form of review is especially designed for reviewing topics that have been conceptualized and studied variously by different groups of researchers. It can be used to overview a complex topic area, highlighting the relative strengths and limitations of the respective research approaches (Wong et al., 2013) and is similar to the methodology used by Hogreve and Gremler (2009) in their review.

Second, when analyzing health care customer roles in service research (including marketing, consumer behavior and operations management journals), a systematic review method was employed. This method uses a documented research process with criteria for inclusion and exclusion of selected articles (Tranfield et al., 2003). The systematic review comprises the following steps: (1) state research questions; (2) develop guidelines for collecting literature deciding on inclusion and exclusion criteria; (3) develop a comprehensive search plan for finding literature; (4) develop a codebook for classifying and describing literature; (5) code the literature; and (6) synthesize the literature (Tranfield et al., 2003). In the following section, the review process is outlined.

\section{Health care research sample}

First, electronic database searches in PubMed and CINAHL, widely used in health care research, were undertaken. To capture different conceptualizations of the role of the health care customer, domain experts were consulted to assist in developing relevant search terms. This resulted in the following key terms: "patient centered” and "person centered” (“care”, "communication”, “medicine”); "holistic care”; “patient empowerment”; "self-management”; “shared decisionmaking”; "professional-patient relations”; "self-care”; "biopsychosocial model”; "patient participation”; “collaborative care”; “patient involvement”; “patient participation”; “patient engagement”; "patient compliance”; and "patient empowerment". 
The initial search revealed a large number of articles. For example, Patient Centeredness alone generated over 20,000 articles. The focus was not to cover every article ever published on the topic, but rather to provide a review of different conceptualizations of the role of the customer in health care research. To enable this, a combination of tracking early articles (when the concept first appeared), the most cited articles, and more recent articles was employed. Due to the large amount of articles, the conventional approach of including only articles published in scientific journals was used. To be included, articles had to be published in English and be peer-reviewed. The aim of this approach was to capture conceptualizations of roles, their development and modification over time, and to identify key references. As suggested by Hogreve and Gremler (2009), the search was supplemented by scanning the reference list of the identified articles in order to identify any other articles that fit the criteria. One hundred articles met the criteria. Each article was then read in detail.

\section{Service research sample}

For the second sample, a systematic review method (Tranfield et al., 2003) was employed to capture different conceptualizations of the role of the health care customer in service research. The search was undertaken as follows. All ISI-rated journals that included "service”, “marketing”, “operations”, “customer” or “consumer” in the title were included in order to capture the health care customer role specifically in the field of service research. This resulted in a total of 34 journals. To ensure that relevant articles were included, a broad search strategy was used. In a first step, an electronic search for articles that used the terms "patient” or "health" or "medicine" in the title, abstract, or keywords including both empirical and conceptual articles was undertaken. The initial search identified 1807 articles published between 1990 and 2016. All of the abstracts were scanned and those that included health care customers or patients in any way, were selected for further analysis. This resulted in 262 articles which were studied in depth. 


\section{Definitions}

Consistent with recommendations for reporting literature reviews in a systematic way (Wong et al., 2013), both reviews are reported together. First, prevalent practice approaches in both samples were identified. In this study, a practice approach is conceptualized as the organizing framework that defines the various roles and associated activities and interactions within the context of health care. Thus, it is a conceptual model of a social system in which roles and complex relations between customers and professionals are allowed to emerge (see Lave and Wenger, 1991). The boundaries of this system are dynamic, ranging from an immediate situation at hand to more complex relations between the parties, distributed in time and space. Role may be defined as a function performed driven through formal and informal institutional rules and procedures (Akaka and Chandler, 2011).

\section{Analysis}

Thematic analysis was used to identify and categorize articles depending on the particular conceptualization of the customer role (Braun and Clarke, 2006). Two authors independently coded the conceptualizations and associated practice approaches into preliminary working themes of practices and then conferred using a process of abstracting and generalizing from specific observations by means of constant comparison, coding and memo procedures (Spiggle, 1994; Strauss, 1987). Following established practice, two authors discussed all of the cases on which they disagreed and used a third author as judge to resolve any discrepancies. Discussions continued until agreement of classifications was reached. Within each of the identified themes, the conceptualization, main contribution, roles and associated activities of both the health care customer and health care professionals are articulated.

To provide additional verification that the key practice approaches and different customer roles in health care were captured an expert panel of ten health care professionals, consisting of 
medical professors, medical practitioners, physicians, senior health administrators, senior nurses and allied health care professionals was consulted. The domain expert panel was deliberately broadly-based to provide insights across a wide range of health care professionals. Panel members were asked to carefully consider the conceptualizations of the key practice approaches and examples and provide feedback. All domain experts verified the authenticity of the practice approaches and that the range of key practice approaches had been adequately captured. In addition, they provided helpful suggestions on specific areas for future research.

\section{What we know}

Practice approaches and conceptualizations of health care customer roles

The role of the health care customer has been conceptualized and studied under a number of different practice approaches (i.e. the underlying philosophy and the associated behaviors). To better understand the role of the health care customer, the roles of the respective health care professionals were also explored. Ten practice approaches were identified, nine originating in health care research and one in service research. These are: (1) Traditional Medical Model; (2) Biopsychosocial Model; (3) Patient Centeredness; (4) Patient Participation; (5) Shared DecisionMaking; (6) Patient Empowerment; (7) Person-Centered Care; (8) Collaborative Care; (9) SelfManaged Care; and (10) Health Care Value Co-creation. Each practice approach is summarized in Appendix 1, identifying the conceptualization, disciplinary origins, overall contribution of the approach and illustrative references. The respective roles of the health care customer and professionals for each of the practice approaches are provided in Table I.

-Insert Table I about here-

In the Traditional Medical Model (TMM), which historically has been the predominant practice approach, the focus is on the disease rather than the person. The doctor is viewed as an authority and decision-maker. In this approach, the role of the health care customer has been 
viewed essentially as a passive recipient of care (Wagner et al., 2005). Following the work of Leino (1952), Patient Centeredness was introduced with the view to providing guidance to nurses on how to work with a focus on the patient. However, the predominant approach adopted by doctors continued to be the Traditional Medical Model through the 1960s and into the late 1970s and is still practiced today by some. In 1977 Engel and Roter, respectively, introduced the Biopsychosocial Model and Patient Participation as new practice approaches. Stemming from psychiatry, the Biopsychosocial Model was introduced because the traditional approach was viewed as inadequate (Engel, 1977). Core elements of the Biopsychosocial Model are that it considers social, psychological and biomedical aspects in the treatment of patients (Gatchel et al., 2007). As such, it offers a broader perspective to understanding suffering, disease and illness on multiple levels (Borrell-Carrió et al., 2004). Patient Participation emphasizes the health care consumer's right to information, choice, voice and safety (Longtin et al., 2010), with the core element being to activate and increase the participation of the patient in different aspects of their care (Roter, 1977).

Patient Centeredness, had its origins in medicine and nursing (Balint, 1969; Leino, 1952), and is referred to by a number of terms, such as Patient Centered Care (PCC), Patient Centered Medicine, and Patient Centered communications, sometimes used interchangeably (Epstein et al., 2005). PCC was popularized by the Picker Institute and the Institute of Medicine (Berghout et al., 2015). While a clear definition of PCC is lacking (Kitson et al., 2013; Rathert et al., 2012), there is some agreement that it comprises the following dimensions: (1) respect for patients' values, preferences, and expressed needs; (2) coordination and integration of care; (3) information, communication, and education; (4) physical comfort; (5) emotional support; (6) involvement of family and friends; (7) transition and continuity; and (8) access to care and services (Gerteis et al., 1993; Jenkinson et al., 2002; Rathert et al., 2012). Core elements in the different approaches 
to Patient Centeredness relate to considering both the disease and the person, respecting the patients' values and needs, enhancing the patient-professional relationship and communication, coordinating care in a patient centered way, and involving patients in care and decision-making.

The practice of Shared Decision-Making (SDM) emerged from the increased interest in a more customer-centered care approach and an increased focus on patient autonomy in health care interactions (Frosch and Kaplan, 1999). The core elements of SDM are: (1) sharing information and expertise; (2) negotiating and discussing options; and (3) making medical decisions on mutual agreement between patient and professionals. Hence, a distinctive feature of SDM is the mutual process, in which both patients and professionals must be active and involved.

As the name suggests, a key focus of Person-Centered Care is an emphasis on the "whole person”. Core elements of Person-Centered Care are: (1) to consider the person seeking counseling is an expert on him/her self; (2) to address the person's holistic and specific assets including individual, social and contextual factors; and (3) to place emphasis on the relationship and communication between health care professionals (and others) and the health care customer. Using the term "person", instead of "patient", aims to highlight a move away from a passive role where the patient is seen as someone, or worse still a "body", to be “acted on”. Person-Centered Care emphasizes the person behind the patient with feelings, needs and a will with the goal of engaging the person as an active partner in decision-making, care and treatment (Ekman et al., 2011). Furthermore, Person-Centered Care relies on the knowledge of the whole person (Starfield, 2011). Person-Centered Care shares similar elements with Patient Centeredness but puts more emphasis on the partnership between the customer and the professionals, starting with the patient's narrative - highlighting that the individual person is the starting point and focus of care. As with Patient Centeredness and Collaborative Care, this approach is rather broad and 
encompasses elements of other practices such as Shared Decision-Making, Patient Participation and Patient Empowerment.

Evolving within the management of chronic illness and psychiatry, the Collaborative Care practice approach presents a comprehensive framework for collaboration between the customer, the health care providers and other professionals (Callahan et al., 2006; Von Korff et al., 1997). This approach differs from the previous approaches in that the scope is broader than the traditional patient-professional dyad. In contrast to other practices, such as Patient Centeredness, Self-Managed Care acknowledges the patient's activities both inside and outside the health care setting.

From 2000 onwards there has been a series of service research papers published on the role of the health care customer adopting practice approaches, such as the Traditional Medical Model, Patient Centeredness and Self-Managed Care, from health care research and transferring it to service research. Examples include for instance, Ouschan et al. (2000), Berry and Bendapudi (2007), Gallan et al. (2013) and Seiders et al. (2015). Most recently, a new practice approach has emerged from service research that focuses on Health Care Value Co-creation, notably McCollKennedy et al. (2012, 2016), Sweeney et al. (2015) and Tian et al. (2014). The core element of Health Care Value Co-creation is that the customer is an active co-creator of value and a collaborator in care, albeit to varying extents, depending on how the customer perceives the benefits (that is, perceived value).

Traditionally, service research and health care have been two separate research fields. However, service researchers have begun to focus more on the health care service setting (e.g., Berry and Bendapudi, 2007; Elg et al., 2012; McColl-Kennedy et al., 2012, 2016; Ozanne and Anderson, 2010) as it provides a rich context in which to explore a wide range of constructs (Ostrom et al., 2015). The service perspective stretches beyond identifying customer needs, to 
actively collaborating with, and learning from customers as well as customers learning from other customers in order to adapt to their individual needs (Vargo and Lusch, 2004). Instead of passively receiving goods and services, customers actively contribute, co-creating value with the service provider and others in their service network or ecosystem (Frow et al., 2016; McCollKennedy et al., 2012).

While Collaborative Care and Self-Managed Care approaches imply co-creation of value they do not explicitly use the term. Further, the Health Care Value Co-creation practice approach acknowledges that: (1) health care customers will co-create value in differing ways; and (2) integrate different sets of resources, with potentially a wide range of collaborators. For example, some health care customers may see value in engaging in many and varied activities and interactions, while others would rather engage in fewer activities and interactions to co-create value. The critical point from this perspective is to recognize that value is realized in a range of ways; it is phenomenologically and contextually determined by the individual. Therefore, cocreation practices should be customized to the individual customer and methods and processes adjusted accordingly.

Established effects of the roles of the health care customer in the different practice approaches Having identified the ten main practice approaches, highlighting the respective roles of both the health care customer and health care professionals and the attendant types of practices (activities and interactions) within each approach, an important question is what is the effect of the changing role of the health care customer on key outcomes, such as satisfaction, quality of life and health outcomes. Table II provides a summary of identified effects of specific health care customer roles for each practice approach. These effects are now discussed in turn.

- Insert Table II about here - 
In the Traditional Medical Model and the Biopsychosocial Model where it is taken as a given that the role of the customer is to comply, understandably there are no studies on the different roles of the health care customer or how their role has changed. However, in the remaining eight practice approaches, several effects are identified.

First, considerable interest on the effects of the role of the customer have been evident in research in Self-Managed Care and Shared Decision-Making. In Self-Managed Care, changing the health care customer role to that of a self-manager has been shown to reduce hospital costs (Lorig et al., 2001), increase patient satisfaction (Lorig et al., 2008), improve health outcomes (Vetter-Smith et al., 2012), and lower overall mortality (Stock et al., 2010). Nonetheless, in the shared decision realm, Botti et al. (2009) find that in situations of "tragic choice" where customers perceive causality for making decisions, there is more negative emotion than when the choice is made externally. However, there is also evidence that when the health care customer is a decision sharer there is higher patient satisfaction (Jahng et al., 2005), and higher levels of quality of life (Street and Voigt, 1997).

Stewart (1984) found that when a health care customer accepts the invitation to participate there tends to be decreased drug use and improved patient satisfaction. Kinmonth et al. (1998) showed that training clinicians in Patient Centeredness improved health care customer well-being and reduced the risk of further diseases. Anderson et al. (1995) identified improved glucose control as well as psychosocial effects of empowering diabetic health care customers. Recently, research on health care customer value co-creation showed that when health care customers accept and put effort into their role as co-creators of value this positively impacts customer satisfaction and quality of life (e.g., Sweeney et al., 2015).

\section{What service research can contribute to health care}

As health care outcomes in general are highly dependent on activities of the customer (Bitner et 
al., 1997), there is a need to understand how a more active role of the customer can be incorporated into health care service delivery. Clearly, the notion of a more active health care customer role is gaining increased attention in several fields of health care research. During the last decade, health care researchers have been developing a variety of practice approaches promoting a more active health care customer across a range of diseases. Methods, tools and techniques for involving health care customers in service delivery, as well as theoretical approaches have been developed. Despite interest in both research and practice over the last few decades in making health care more customer-centered, models in health care remain "fundamentally the same” (Gibson et al., 2012, p. 531). Often the process of involving health care customers focuses on isolated encounters, such as medical consultations or a specific decision regarding treatment (Thompson, 2007), or through workplace wellness programs (e.g. Maynard 2008). Yet, Berry and Bendapudi (2007, p. 121) suggest, "health care poses many questions that service researchers could pursue. As professionals, we have an opportunity to help shape the future of health care service delivery".

In the field of service operations, perhaps surprisingly, the role of the health care customer is rarely discussed. Health care studies within service operations provide valuable insights into how to optimize patient queuing models (e.g., Su and Zenios, 2004), managing patient service (e.g., Green et al., 2006), how operational failures are impacting nurses and patients (Tucker, 2004), leadership effects on patient safety (McFadden et al., 2009), and how electronic advice impacts patient satisfaction (Queenan et al., 2011).

In service marketing, studies in the context of health care are focused on topics related to patient satisfaction (e.g., Choi et al., 2005), service quality (e.g., Dagger et al., 2007), service culture (e.g., Wong and King, 2008), responses to health messages (Keller, 2006), or patient loyalty (e.g., Moliner, 2009). While few research papers conceptualize or discuss the role of the 
health care customer specifically, exceptions include for example, the customer's role in relation to preventive health behaviors in the health setting (Moorman and Matulich, 1993; Zainuddin et al., 2013) as well as outside the health care setting (Jayanti and Burns, 1998), and alternative therapies (Rajamma and Pelton, 2010). Others investigate underlying factors influencing the health customer's adherence to expert advice (Logie-MacIver and Piacentini, 2010; Seiders et al., 2015; Spanjol et al., 2015) and customer readiness, acceptance and use of health e-services (Hardey, 2010; Schuster et al., 2012). Yao et al. (2015) expand the investigation of the use of health e-services to the peer-to-peer domain in their examination of online communities for stigmatized customers and the impact on their physical, psychological and existential quality of life. In addition, transformative service research is broadening the focus to more customer wellbeing outcomes such as quality of life, well-being, access, stress, inclusion, community, and marginalization (see for example, Rosenbaum and Smallwood, 2011, 2013; Sweeney et al., 2015; Yao et al., 2015; Zayer et al., 2015). However, further research is needed to more fully understand the effects of the changing role of the health care customer.

McColl-Kennedy et al. (2012) explicitly explore health care customers' roles by investigating how customers actually engage in value co-creation by identifying the customers’ perceived role, activities and interactions. Research shows that significant numbers of customers want to interact and co-create value, and not necessarily with just one service provider but also with communities of professionals, service providers, and other customers (McColl-Kennedy et al., 2012). Adopting this approach would require considerable cultural change. Accepting the view that health care is not merely a transaction between the clinician and individual health care customer, but rather active collaboration between different actors in their ecosystem (such as family, friends, health information sites, and online health communities), means that the roles, activities, interactions, and responsibilities of health care customers and professionals change 
(Frow et al., 2016). Tian et al., (2014, p. 256) highlight the role of health care customers, whom they label "health seekers", in using digital entertainment to bring about a more human face to health care, focusing particularly on "preventative, holistic, cocreated community-supported endeavors”.

It is encouraging to see that some health care researchers have started using the value cocreation model in their research to better engage multiple stakeholders and end users in cocreating value in the research outcomes. Indeed, Janamian et al., (2014) have reported that the interlocking of multiple stakeholders (the end users) and researchers across the research journey increases the research translation and utility of the outcomes. Notwithstanding, the hierarchical power structures and professional barriers in institutional practices remain a major obstacle (Greenhalgh et al., 2010). Also it must be recognized that not all health care customers may be willing to adopt a more active role. Thus, much remains to be done to achieve greater acceptance of the increasingly active role of the health care customer by both health care professionals and health care customers.

Importantly, it must be noted that using a practice approach where health care customers are more active, should not be seen as a threat to the health professions. Commitment to involve and co-create value with health care customers also does not imply that professionals must provide health care to customers, just because they request it. In contrast to other services, health care is highly regulated, and health care customers (and in some cases, health professionals) cannot completely choose which services, treatments, or medications they want (Bower, 2003). Therefore, a significant responsibility still lies with clinicians to initially propose treatment options to the individual health care customer and then work with the health care customer and other health professionals to co-produce health care options.

\section{What service research can learn from health care}


First, several practice approaches from health care research, especially the Traditional Medical Model, Patient Centeredness and Self-Managed Care have been used in service research. This has enabled the transfer of concepts, knowledge and experience related to a changed health care customer role from passive to active to be applied in service research.

Second, health care as a context has been described as a fertile area for service research (Berry and Bendapudi, 2007), but what can service researchers take from this context to enrich the development of theory in service research? As theory is developed in a particular context, there is opportunity to learn from that theory and to test and adapt it to other contexts. Thus, by studying a "negative” service where customers are "sick", reluctant, in need of privacy and risking their life (Berry and Bendapudi, 2007), researchers can advance service theories, testing if they can explain how service works in such a context (Voss et al., 2016). The role of the health care customer may differ depending on the diagnoses and prognoses, which brings in a temporal dimension in service research. For instance, a customer with an ongoing illness such as cancer cannot be treated in a similar way to a patient who requires hand surgery. Clearly, one diagnosis might involve a long-term treatment with chemotherapy and be detrimental to the person's overall health, while other diagnoses might be treated and cured through a surgical procedure.

The customer role in health care illustrates the need for adequately preparing the ecosystem actors for this change. To prepare for new roles, both health care customers and professionals need to be educated and empowered. To understand what constitutes the change in the customer role and how to manage such a change is an important research gap, and therefore the authors encourage systematic work that explores and develops service theory and practice further.

Thus far, studies of customers in health care have provided new ideas about co-creative practices (McColl-Kennedy et al., 2012, 2016; Tian et al., 2014), the role of positivity for 
customer participation (Gallan et al., 2013), and customer adherence to expert advice (Seiders et al., 2015). The next section outlines an agenda for future research to address important research gaps. These theories can be used in models for both B2B and B2C customers. Studies in a context where the customer's role is changing provides researchers with an excellent opportunity to explore in depth and identify new understandings of what role(s) a customer is willing to adopt and consequently build theory.

\section{What we still need to know: A research agenda for health care service research}

The proposed research agenda highlights seven important areas of inquiry designed to help advance deeper understanding of the health care customer. These are: (1) managing co-creative practices; (2) better understanding of roles during value co-creation; (3) co-production models for innovation and development; (4) the effects of changing health care customer roles; (5) dysfunctional health care customer behavior; (6) use of technology to enhance the health care experience; and (7) conditions underlying negative services. The research agenda is outlined below and summarized in Table III.

- Insert Table III about here -

Managing co-creative practices. Service research has identified that co-creative practices cannot be managed without supportive leadership and appropriate managerial processes (Payne et al., 2008; Ramaswamy, 2009). In health care there are many barriers that need to be understood in order to manage co-creative practices (Bohmer, 2009). Values, norms and a strong professional culture, as well as formal and legal arrangements, place specific demands on how to manage health care services. Managing and organizing for better value co-creation among the multiple players places attention on the establishment of organizational strategy, structure, and process that facilitate new co-creative practices. Considerable work in different practice approaches, and particularly patient involvement, focuses on the specific patient-professional 
roles, leaving a research gap on how to handle this issue at the strategic level. Managing such services concerns not only managing a team of professionals, rather it means managing a team of doctors, allied health care professionals, nurses, and health care customers and their families within the specific organizational context and the larger health care system. A critical question therefore is how to reorganize health care organizations and assist in embedding new forms of health care where customers are viewed as, and allowed to be, better co-creators of value and at times co-producers of service(s)? Other related important research questions are:

- What are the underlying mechanisms that link health care customers and organizations?

- How should health care organizations be re-designed to better support co-creative practice principles?

- How should new practices be embedded to enable customers and professionals to better co-create value and co-produce service(s)?

Better understanding of roles during value co-creation. The move from being a passive receiver of care to an active co-producer that takes part in decision-making and in the delivery of care requires not only new ways of organizing health care but also a change in the behaviors of employees (Bowen, 2016). A central question is how to prepare and meet this changing role, especially since the variation in the behavior of health care customers will increase at both the individual level and for different forms of care. A health care customer is a resource integrator, applying a unique set of skills and resources to improve their well-being. Health care customers, who suffer from specific combinations of illness, pain, uncertainty and fear, might not be willing or able to take an active role (Berry and Bendapudi, 2007; Botti et al., 2009). In the treatment of episodic illnesses (e.g., hip surgery) the customers are subject to a standardized care process where the service provider, to a large extent, defines the process and the duration is limited in 
time and scope. Customers experience these health problems only temporarily and their understanding of the illness and treatment procedures is often limited and fragmented. In contrast, when dealing with ongoing and chronic illnesses, customers are often experts in their own disease or conditions and can have greater influence on their care (Bodenheimer et al., 2002, McColl-Kennedy et al., 2012, 2016; Spanjol et al., 2015). Understanding what processes, tools, and business practices are useful in defining, motivating, and managing health care customer and employee roles is important to succeed with service provision in health care. Specifically, future research should address the following questions.

- How are the respective roles of health care customers and the various other health professionals defined during value co-creation?

- What processes, tools, and business practices are useful in defining, motivating, and managing health care customer and employee roles?

- How should the respective roles of each player be conveyed to the other parties involved in value co-creation?

- How should the various activities and interactions of the players be integrated to provide a seamless health care experience?

Co-production models for innovation and development. Research has shown that sick and reluctant health care customers (Berry and Bendapudi, 2007) are interested in and can contribute to service innovation. In a wide range of areas such as medical devices, social support, information technology and clinical processes, health care customers may contribute to new designs of products and services. Health care customers have unique knowledge of their own health care problem and its treatment, and so they may have ideas about how service delivery can support them in their everyday life (Tian et al., 2014). This could include for instance, apps for 
self-diagnosis and/or monitoring skin cancers, reminding health care customers to take their medication and experimenting with the timing of when medication is taken. From a customer perspective, the care process is not over when the customer leaves the hospital or clinic, it continues at home in every-day living (McColl-Kennedy et al., 2012, 2016; Spanjol et al., 2015). As such, the specific characteristics of health care customers make it an interesting context for research on customer creativity and service innovation. Future research could focus on the following research questions.

- In what ways can health care customers contribute to the design of new products and services?

- How can technology better enable health service to continue to be provided, coproduced and coordinated in the patient's home?

The effects of changing health care customer roles. Research on evaluating the effects (outcomes) of changing the role of the customer is limited, especially when considering the large number of studies that have been undertaken, and that the tradition in health care is to look for evidence based effects through clinical trials (Abel and Koch, 1999). However, three types of effects have been identified: (1) improved customer perceptions of care and quality of life; (2) improved operational performance; and (3) improved health outcomes. Yet, too often the identified effects are limited to multiple case studies (e.g., Vetter-Smith et al., 2012) and studies with small sample sizes. This is particularly true when moving beyond the effects of customer perception towards effects on health outcomes. Accordingly, there is a need to identify effects that are of interest, can be accepted at the policy, administrative and professional levels, and that can demonstrate the positive and negative effects of a changed role of the health care customer in value co-creation and co-production. Given the long tradition of clinical trials in medicine and 
related disciplines (Abel and Koch, 1999; Peto and Baigent, 1998), clinical trials and experiments are encouraged. This was also highlighted by the medical panel that argued "if you want to set forward a new approach to patient roles and how to organize and implement health care, you need to be clear that it is the prevailing paradigm that is the biggest obstacle since it is based on a great faith in evidence (preferably randomized trials then). So it becomes important to provide evidence, to prove that the new ways of working with patients may be more efficient and better for the patients and for the profession and the rest of the population.” Hence:

- $\quad$ How can we better understand the effect of the changing role of the customer at the various touchpoints in the customer journey?

- What metrics can be used to capture shared decision-making (choices) across touchpoints in the customer journey and their effects on outcomes?

Dysfunctional health care customer behavior. Even if patients need health care, they may be unwilling to take a role that supports the co-production of health. In fact, health care customers may even sabotage treatments in different ways. For example, medication compliance is typically around $50 \%$, and even lower for treatments that aim to change lifestyle or behavior (Haynes et al., 2002). Several theories explaining customer health care behavior have discussed dysfunctional health care customer behavior. Smith and Wallston (1992) among others, argue that customers incorporate health care behavior that is in line with how they value health and how important they consider their health to be. In addition, health care customers are not always rational in their behavior or in adopting a specific role. For instance, if the value of health care and consequences of a treatment are not explicit to customers in the short-term, they may behave paradoxically in health care, such as not disclosing important medical information, lying or even sabotaging treatments. Furthermore, they may not wish to accept short-term pain for long-term 
gain (McColl-Kennedy et al., 2016; Mischel et al., 1989). Hence, the following research questions hold promise.

- What motivates health care customers to lie/not disclose important medical information required in treatments?

- Why do some health care customers sabotage treatments?

- Why do some health care customers refuse "healthy" choices?

Use of technology to enhance the health care experience. In health care, technology has a long standing tradition for innovating treatment methods, surgery and interaction between health care customers and professionals. There are specific service innovation models that help researchers to understand health service innovation and how to capture both incremental and radical changes in health care services (Windrum and García-Goñi, 2008). Recently, information and communications technology has opened up possibilities for completely new types of services (Ostrom et al., 2015). For example, Internet services can be used to increase knowledge of illnesses, symptoms and possible treatment and has changed customer-professional interactions. The introduction of services such as remote health monitoring and smart devices that track and analyze health information have the potential to change customer-professional encounters even more with in-depth individualized knowledge of customer behaviors. In addition, technology can be used to either standardize or customize health care service provision and solve access to health care services (see Ostrom et al., 2015). However, it also opens up ethical issues, such as how intrusive such tracking services and wearable technologies can be for the health care customer, and how health care professionals should use the information provided by such technology. Hence: 
- How can technology be used to assist in decision-making on treatment plans to minimize errors?

- What is the impact of wearing tracking devices on health care customer behavior?

- What are the ethical considerations that need to be taken into account by health professionals?

- Does the technology enhance or hinder compliance on the part of the health care customer? Why?

Conditions underlying negative services. Research on services most often focuses on positive or neutral services, rather than on "negative” services (Berry and Bendapudi, 2007). However, customer engagement, behavior, reactions and expectations in negative services may differ from traditional services. In the new role where customers are considerably more active, even drivers of their own health and well-being, and health care services are "outsourced", moves the customer into a complex participative system putting more responsibility on the individual customer (Mifsud et al., 2015). These specific circumstances can create complications when customers have to carry out unwanted, complex tasks over long or indefinite periods of time (Spanjol et al., 2015). Shifting responsibility to the health care customer might be problematic as the medical panel points out that they (the patients) “don’t always have the knowledge and understanding, for example, why they should take their medicines”. It is also important to note that not all health care customers wish to or can be actively involved, or that an active customer role always leads to better outcomes. As another domain expert points out, "another interesting question is does the patient want to be a customer, and if so, to what extent? Are we putting too much responsibility on the patients?” While it has been suggested that health care services are coproduced by health care practitioners and customers who collaborate in treatment, Creer and 
Holroyd (2006) contend that in reality, health activities are mostly the sole responsibility of the individual customer. To do this successfully requires knowledge, skills, motivation, and daily problem solving (Lorig and Holman, 2003). Hence, it would be worthwhile to investigate the following research questions.

- What are the characteristics of patients who are motivated to take on high levels of responsibility?

- What kinds of emotional support do patients need when they are involved in decision-making?

\section{Conclusion}

In this review of the changing health care customer role, the authors have attempted to synthesize the health care and service research literatures. The review reveals ten key practice approaches, and identifies an increased activation of the health care customer's role over time. This change implies a re-orientation from the "medical gaze" of an authoritative figure who prescribes and the patient merely acquiesces, to the customer actively contributing and co-creating value with an array of health service providers and other players in the service ecosystem to the extent that the customer desires.

The identified effects of changing the health care customer role reveal that such a role can improve satisfaction, quality of life and health outcomes. However, a change in the customer's role does not automatically lead to positive effects. Indeed, there is a need to further investigate both the positive and negative effects of the changed customer role. When health care is no longer viewed simply as a transaction between the customer and professional, but instead relies on collaboration between multiple actors in an ecosystem, the roles, activities, and responsibilities of health care customers and professionals change. It also highlights the 
importance of the customer's broader network, such as family and friends and other health care customers. Clearly, much still remains to be done, and accordingly the authors provide a compelling research agenda along seven important avenues designed to move forward health care service research.

\section{References}

Abel, U. and Koch, A. (1999), "The role of randomization in clinical studies: myths and beliefs", Journal of Clinical Epidemiology, Vol. 52 No. 6, pp. 487-497.

Adams, R.J., Smith, B.J. and Ruffin, R.E. (2001), "Impact of the physician’s participatory style in asthma outcomes and patient satisfaction”, Annals of Allergy, Asthma \& Immunology, Vol. 86 No. 3, pp. 263-271.

Akaka, M.A. and Chandler, J.A. (2011), "Roles as resources: a social roles perspective of change in value networks", Marketing Theory, Vol. 11 No. 3, pp. 243-260.

Anderson, L., Ostrom, A.L., Corus, C., Fisk, R.P., Gallan, A.S., Giraldo, M., Mende, M., Mulder, M., Rayburn, S.W., Rosenbaum, M.S., Shirahada, K. and Williams, J.D. (2013), "Transformative service research: an agenda for the future", Journal of Business Research, Vol. 66 No. 8, pp. 1203-1210.

Anderson, R.M. (1995), "Patient empowerment and the traditional medical model: a case of irreconcilable differences?”, Diabetes Care, Vol. 18 No. 3, pp. 412-415.

Anderson, R.M., Funnell, M.M., Butler, P.M., Arnold, M.S., Fitzgerald, J.T. and Feste, C.C. (1995), "Patient empowerment: results of a randomized controlled trial”, Diabetes Care, Vol. 18 No. 7, pp. 943-949.

Balint, E. (1969), "The possibilities of patient-centered medicine”, The Journal of the Royal College of General Practitioners, Vol. 17 No. 82, pp. 269-276.

Barlow, J., Wright, C., Sheasby, J., Turner, A. and Hainsworth, J. (2002), "Self-management approaches for people with chronic conditions: a review", Patient Education and Counseling, Vol. 48 No. 2, pp. 177-187.

Berghout, M., van Exel, J., Leensvaart, L. and Cramm, J.M. (2015), "Healthcare professionals' views on patient-centered care in hospitals", BMC Health Services Research, Vol. 15 No. 1, pp. 1-13.

Berry, L.L. and Bendapudi, N. (2007), "Health care: a fertile field for service research”, Journal of Service Research, Vol. 10 No. 2, pp.111-122.

Bitner, M.J., Faranda, W.T., Hubbert, A.R. and Zeithaml, V.A. (1997), "Customer contributions and roles in service delivery", International Journal of Service Industry Management, Vol. 8 No. 3, pp. 193-205.

Bodenheimer, T., Lorig, K., Holman, H. and Grumbach, K. (2002), "Patient self-management of chronic disease in primary care”, The Journal of the American Medical Association, Vol. 288 No. 19, pp. 2469-2475.

Bohmer, R.M.J. (2009), Designing Care: Aligning the Nature and Management of Health Care, Harvard Business Press, Boston, Massachusetts. 
Bone, P.F., France, K.R., and Aikin, K.J. (2009), “On Break-up Clichés Guiding Health Literacy’s Future”, Journal of Consumer Affairs, Vol. 43 No. 2, pp. 185-198.

Borrell-Carrió, F., Suchman, A.L. and Epstein, R.M. (2004), “The biopsychosocial model 25 years later: principles, practice, and scientific inquiry”, The Annals of Family Medicine, Vol. 2 No. 6, pp. 576-582.

Botti, S., Orfali, K. and Iyengar, S.S. (2009), “Tragic choices: autonomy and emotional responses to medical decisions”, Journal of Consumer Research, Vol. 36 No. 3, pp. 337-352.

Bowen, D.E. (2016), “The changing role of employees in service theory and practice: An interdisciplinary view”, Human Resource Management Review, Vol. 26 No 1, pp. 4-13.

Bower, D.J. (2003), “Innovation in healthcare delivery”, Service Innovation: Organizational Responses to Technological Opportunities \& Market Imperatives, pp. 211-230.

Braun, V. and Clarke, V. (2006), "Using thematic analysis in psychology”, Qualitative Research in Psychology, Vol. 3 No. 2, pp. 77-101.

Callahan, C.M., Boustani, M.A., Unverzagt, F.W., Austrom, M.G., Damush, T.M., Perkins, A.J., Fultz, B.A., Hui, S.L., Counsell, S.R. and Hendrie, H.C. (2006), "Effectiveness of collaborative care for older adults with alzheimer disease in primary care: a randomized controlled trial”, The Journal of the American Medical Association, Vol. 295 No. 18, pp. 2148-2157.

Charles, C., Gafni, A. and Whelan, T. (1997), "Shared decision-making in the medical encounter: what does it mean? (or it takes at least two to tango)”, Social Science \& Medicine, Vol. 44 No. 5, pp. 681-692.

Choi, K.-S., Lee, H., Kim, C. and Lee, S. (2005), “The service quality dimensions and patient satisfaction relationships in South Korea: comparisons across gender, age and types of service”, Journal of Services Marketing, Vol. 19 No. 3, pp. 140-149.

Courtney, R., Ballard, E., Fauver, S., Gariota, M. and Holland, L. (1996), “The partnership model”, Public Health Nursing, Vol. 13 No. 3, pp. 177-186.

Creer, T.L. and Holroyd, K.A. (2006), "Self-management of chronic conditions: the legacy of Sir William Osler”, Chronic Illness, Vol. 2 No. 1, pp. 7-14.

Dagger, T.S., Sweeney, J.C. and Johnson, L.W. (2007), “A hierarchical model of health service quality: scale development and investigation of an integrated model”, Journal of Service Research, Vol. 10 No. 2, pp. 123-142.

Ekman, I., Swedberg, K., Taft, C., Lindseth, A., Norberg, A., Brink, E., Carlsson, J., DahlinIvanoff, S., Johansson, I-L., Kjellgren, K., Lidén, E., Öhlén, J., Olsson, L-E., Rosén, H., Rydmark, M. and Sunnerhagen, K.S. (2011), “Person-centered care: ready for prime time”, European Journal of Cardiovascular Nursing, Vol. 10 No. 4, pp. 248-251.

Ekman, I., Wolf, A., Olsson, L.-E., Taft, C., Dudas, K., Schaufelberger, M. and Swedberg, K. (2012), "Effects of person-centred care in patients with chronic heart failure: the PCC-HF study”, European Heart Journal, Vol. 33 No. 9, pp. 1112-1119.

Elg, M., Engström, J., Witell, L. and Poksinska, B. (2012), “Co-creation and learning in healthcare service development”, Journal of Service Management, Vol. 23 No. 3, pp. 328-343.

Emanuel, E.J. and Emanuel, L.L. (1992), "Four models of the physician-patient relationship", The Journal of the American Medical Association, Vol. 267 No. 16, pp. 2221-2226.

Engel, G.L. (1977), “The need for a new medical model: a challenge for biomedicine”, Science, 196 No. 4286, pp. 129-136.

Epstein, R.M., Franks, P., Fiscella, K., Shields, C.G., Meldrum, S.C., Kravitz, R.L. and Duberstein, P.R. (2005), "Measuring patient-centered communication in patient-physician 
consultations: theoretical and practical issues”, Social Science \& Medicine, Vol. 61 No. 7, 1516-1528.

Epstein, R.M. and Street, R.L. (2011), “The Values and Value of Patient-Centered Care”, The Annals of Family Medicine, Vol. 9 No. 2, pp. 100-103.

Frosch, D.L. and Kaplan, R.M. (1999), "Shared decision making in clinical medicine: past research and future directions”, American Journal of Preventive Medicine, Vol. 17 No. 4, pp. 285-294.

Frow, P., McColl-Kennedy, J.R. and Payne, A. (2016), “Co-creation practices: their role in shaping a service ecosystem”, Industrial Marketing Management, Vol. 56, pp.24-39.

Gallan, A.S., Jarvis, C.B., Brown, S.W. and Bitner, M.J. (2013), "Customer positivity and participation in services: an empirical test in a health care context”, Journal of the Academy of Marketing Science, Vol. 41 No. 3, pp. 338-356.

Gallefoss, F. and Bakke, P.S. (2000), "Impact of patient education and self-management on morbidity in asthmatics and patients with chronic obstructive pulmonary disease”, Respiratory Medicine, Vol. 94 No. 3, pp. 279-287.

Gatchel, R.J., Peng, Y.B., Peters, M.L., Fuchs, P.N. and Turk, D.C. (2007), “The biopsychosocial approach to chronic pain: scientific advances and future directions”, Psychological Bulletin, Vol. 133 No. 4, pp. 581-624.

Gerteis, M., Edgman-Levitan, S., Daley, J. and Delbanco, T.L. (1993), Through the Patient's Eyes: Understanding and Promoting Patient-Centered Care, Jossey-Bass, San Francisco.

Gibson, A., Britten, N. and Lynch, J. (2012), “Theoretical directions for an emancipatory concept of patient and public involvement”, Health: An Interdisciplinary Journal for the Social Study of Health, Illness and Medicine, Vol. 16 No. 5, pp. 531-547.

Gibson, C.H. (1991), “A concept analysis of empowerment”, Journal of Advanced Nursing, Vol. 16 No. 3, pp. 354-361.

Gilbody, S., Bower, P., Fletcher, J., Richards, D. and Sutton, A.J. (2006), “Collaborative care for depression: a cumulative meta-analysis and review of longer-term outcomes”, Archives of Internal Medicine, Vol. 166 No. 21, pp. 2314-2321.

Gotsman, I., Zwas, D., Zemora, Z., Jabara, R., Admon, D., Lotan, C. and Keren, A. (2011), "Clinical outcome of patients with chronic heart failure followed in a specialized heart failure center”, The Israel Medical Association Journal, Vol. 13 No. 8, 468-473.

Green, L.V., Savin, S. and Wang, B. (2006), "Managing patient service in a diagnostic medical facility”, Operations Research, Vol. 54 No. 1, pp. 11-25.

Greenfield, S., Kaplan, S. and Ware, J. Jr (1985), "Expanding patient involvement in care: effects on patient outcomes”, Annals of Internal Medicine, Vol. 102 No. 4, pp. 520-528.

Greenfield, S., Kaplan, S.H., Ware, J.E. Jr, Yano, E.M. and Frank, H.J.L. (1988), "Patients' participation in medical care”, Journal of General Internal Medicine, Vol. 3 No. 5, pp. 448457.

Greenhalgh, T., Humphrey, C. and Woodard, F. (2010), User Involvement in Health Care, BMJ Books/Wiley-Blackwell.

Gummerus, J., Liljander, V., Pura, M. and van Riel, A. (2004), “Customer loyalty to contentbased Web sites: the case of an online health care service,” Journal of Services Marketing, Vol. 18 No. 3, 175-186.

Hardey, M. (2010), “Consuming Professions User-review websites and health services”, Journal of Consumer Culture, Vol. 10 No. 1, pp. 129-149. 
Hardyman, W., Daunt, K.L. and Kitchener, M. (2015), "Value co-creation through patient engagement in health care: a micro-level approach and research agenda”, Public Management Review, Vol, 17 No. 1, pp. 90-107.

Haynes, R., McDonald, H.P. and Garg, A.X. (2002), "Helping patients follow prescribed treatment: clinical applications”, The Journal of the American Medical Association, Vol. 288 No. 22, pp. 2880-2883.

Hogreve, J. and Gremler, D.D. (2009), “Twenty years of service guarantee research: a synthesis”, Journal of Service Research, Vol. 11 No. 4, pp. 322-343.

Institute of Medicine (US) Committee on Quality of Health Care in America (2001), Crossing the Quality Chasm: A New Health System for the 21st Century, National Academies Press.

Jahng, K.H., Martin, L.R., Golin, C.E. and DiMatteo, M.R. (2005), "Preferences for medical collaboration: patient-physician congruence and patient outcomes”, Patient Education and Counseling, Vol. 57 No. 3, pp. 308-314.

Janamian, T., Jackson, C.L. and Dunbar, J.A. (2014), “Co-creating value in research: stakeholders’ perspectives”, The Medical Journal of Australia, Vol. 201 No. 3, pp. s44-46.

Jayanti, R.K. and Burns, A.C. (1998), "The antecedents of preventive health care behavior: an empirical study”, Journal of the Academy of Marketing Science, Vol. 26 No. 1, pp. 6-15.

Jenkinson, C., Coulter, A. and Bruster, S. (2002), “The Picker patient experience questionnaire: development and validation using data from in-patient surveys in five countries”, International Journal for Quality in Health Care, Vol. 14 No. 5, pp. 353-358.

Keller, P.A., Harlam, B., Loewenstein, G. and Volpp, K.G. (2011), "Enhanced active choice: A new method to motivate behavior change”, Journal of Consumer Psychology, Vol. 21 No. 4, pp. 376-383.

Kinmonth, A.L., Woodcock, A., Griffin, S., Spiegal, N. and Campbell, M.J. (1998), "Randomised controlled trial of patient centred care of diabetes in general practice: impact on current wellbeing and future disease risk”, British Medical Journal, Vol. 317 No. 7167, pp. 1202-1208.

Kitson, A., Marshall, A., Bassett, K. and Zeitz, K. (2013), "What are the core elements of patientcentred care? A narrative review and synthesis of the literature from health policy, medicine and nursing”, Journal of Advanced Nursing, Vol. 69 No. 1, pp. 4-15.

Kitwood, T. (1997), Dementia Reconsidered: The Person Comes First, Open University Press.

Kremer, H., Ironson, G., Schneiderman, N. and Hautzinger, M. (2007), “'It’s my body’: does patient involvement in decision making reduce decisional conflict?”, Medical Decision Making, Vol. 27 No. 5, pp. 522-532.

Lave, J. and Wenger, E. (1991), Situated Learning: Legitimate Peripheral Participation, Cambridge University Press, Cambridge.

Leino, A. (1952), “Planning patient-centered care”, The American Journal of Nursing, Vol. 52 No. 3, pp. 324-325.

Logie-MacIver, L. and Piacentini, M.G. (2010), “Towards a richer understanding of consumers in social marketing contexts: revisiting the stage of change model”, Journal of Marketing Management, Vol. 27 No. 1-2, pp. 60-76.

Loh, A., Simon, D., Wills, C.E., Kriston, L., Niebling, W. and Härter, M. (2007), "The effects of a shared decision-making intervention in primary care of depression: a cluster-randomized controlled trial”, Patient Education and Counseling, Vol. 67 No. 3, pp. 324-332.

Longtin, Y., Sax, H., Leape, L.L., Sheridan, S.E., Donaldson, L. and Pittet, D. (2010), "Patient participation: current knowledge and applicability to patient safety”, Mayo Clinic Proceedings, Vol. 85 No. 1, pp. 53-62. 
Lorig, K.R. and Holman, H.R. (2003), "Self-management education: history, definition, outcomes, and mechanisms”, Annals of Behavioral Medicine, Vol. 26 No. 1, pp. 1-7.

Lorig, K.R., Ritter, P.L., Dost, A., Plant, K., Laurent, D.D. and McNeil, I. (2008), "The expert patients programme online, a 1-year study of an Internet-based self-management programme for people with long-term conditions”, Chronic Illness, Vol. 4 No. 4, pp. 247256.

Lorig, K.R., Ritter, P., Stewart, A.L., Sobel, D.S., William Brown, B. Jr, Bandura, A., Gonzalez, V.M., Laurent, D.D. and Holman, H.R. (2001), "Chronic disease self-management program: 2-year health status and health care utilization outcomes”, Medical Care, Vol. 39 No. 11, pp. 1217-1223.

Lusch, R. (2011), "Reframing supply chain management: a service-dominant logic perspective”, Journal of Supply Chain Management, Vol. 47 No 1, pp. 14-18.

MacGregor, J.C. and Wathen, C.N. (2014), “'My health is not a job’: a qualitative exploration of personal health management and imperatives of the 'new public health'”, BMC Public Health, Vol. 14 No. 1, p. 726.

Makoul, G. and Clayman, M.L. (2006), “An integrative model of shared decision making in medical encounters”, in Patient Education and Counseling, EACH Conference 2004, Bruges, Belgium, 14-17 September 2004, Vol. 60 No. 3, pp. 301-312.

Manias, E. and Williams, A. (2008), "Managing pain in chronic kidney disease: patient participation in decision-making”, Journal of Advanced Nursing, Vol. 61 No. 2, pp. 201210.

Maynard, L.J. (2008), "Short-term impact of a voluntary health intervention on overall vs. preventive healthcare consumption”, International Journal of Consumer Studies, Vol. 32 No. 3, pp. 296-302.

McColl-Kennedy, J.R., Vargo, S.L., Dagger, T.S., Sweeney, J.C. and van Kasteren, Y. (2012), "Health care customer value cocreation practice styles”, Journal of Service Research, Vol. 15 No. 4, pp. 370-389.

McColl-Kennedy, J.R., Hogan, S.J., Witell, L. and Snyder, H. (2016), “Co-creative customer practices: effects of health care customer value cocreation “, Journal of Business Research, In press on line 2 August doi:10.1016/j.jbusres.2016.07.006

McCormack, B. (2004), "Person-centredness in gerontological nursing: an overview of the literature”, Journal of Clinical Nursing, Vol. 13, pp. 31-38.

McFadden, K.L., Henagan, S.C. and Gowen, C.R. (2009), “The patient safety chain: transformational leadership's effect on patient safety culture, initiatives, and outcomes”, Journal of Operations Management, Vol. 27 No. 5, pp. 390-404.

Mead, N. and Bower, P. (2000), "Patient-centredness: a conceptual framework and review of the empirical literature”, Social Science \& Medicine, Vol. 51 No. 7, pp. 1087-1110.

Mifsud, M., Cases, A-S. and N’Goala, G. (2015), "Service appropriation: how do customers make the service their own?”, Journal of Service Management, Vol. 26 No. 5, pp. 706-725.

Mischel, W., Shoda, Y., and M.I. Rodriguez (1989), "Delay of gratification in children”, Science, Vol 244 No. 4907, pp. 933-938.

Moliner, M.A. (2009), "Loyalty, perceived value and relationship quality in healthcare services", Journal of Service Management, Vol. 20 No. 1, pp. 76-97.

Moorman, C. and Matulich, E. (1993), “A model of consumers’ preventive health behaviors: The role of health motivation and health ability”, Journal of Consumer Research, Vol. 20 No.2, pp. 208-228. 
Moran, J., Bekker, H. and Latchford, G. (2008), "Everyday use of patient-centred, motivational techniques in routine consultations between doctors and patients with diabetes”, Patient Education and Counseling, Vol. 73 No. 2, pp. 224-231.

Morton, D.G. (1937), “Modern prenatal care”, The American Journal of Surgery, Vol. 35 No. 2, pp. 225-233.

Osler W. (1901), “The natural method of teaching the subject of medicine”, Journal of the American Medical Association, Vol. XXXVI No. 24, pp. 1673-1679.

Ostrom, A.L., Parasuraman, A., Bowen, D.E., Patrício, L., Voss, C.A. and Lemon, K. (2015), "Service Research Priorities in a Rapidly Changing Context”, Journal of Service Research, Vol. 18 No. 2, pp. 127-159.

Ouschan, R., Sweeney, J.C. and Johnson, L.W. (2000), "Dimensions of patient empowerment”, Health Marketing Quarterly, Vol. 18 No. 1-2, pp. 99-114.

Ozanne, J.L. and Anderson, L. (2010), “Community action research”, Journal of Public Policy \& Marketing, Vol. 29 No. 1, pp. 123-137.

Payne, A.F., Storbacka, K. and Frow, P. (2008), "Managing the co-creation of value”, Journal of the Academy of Marketing Science, Vol. 36 No. 1, pp. 83-96.

Peto, R. and Baigent, C. (1998), “Trials: the next 50 years”, British Medical Journal, Vol. 317 No. 7167, pp. 1170-1171.

Queenan, C.C., Angst, C.M. and Devaraj, S. (2011), “Doctors’ orders: if they're electronic, do they improve patient satisfaction? A complements/substitutes perspective”, Journal of Operations Management, Vol. 29 No. 7-8, pp. 639-649.

Rajamma, R.K. and Pelton, L.E. (2010), “Choosing non-conventional treatments: consumers' attempt at controlling health care”, Journal of Consumer Marketing, Vol. 27 No. 2, pp. 127-138.

Ramaswamy, V. (2009), "Leading the transformation to cocreation of value”, Strategy \& Leadership, Vol. 37 No. 2, pp. 32-37.

Rathert, C., Wyrwich, M.D. and Austin Boren, S. (2012), "Patient-centered care and outcomes: a systematic review of the literature”, Medical Care Research and Review, Vol. 70 No. 4, pp. 351-379.

Rosenbaum, M.S. and Smallwood, J.A. (2011), “Cancer resource centres: transformational services and restorative servicescapes”, Journal of Marketing Management, Vol. 27 No. 13-14, pp. 1404-1425.

Rosenbaum, M.S. and Smallwood, J. (2013), “Cancer resource centers as third places”, Journal of Services Marketing, Vol. 27 No. 6, pp. 472-484.

Roter, D. (1977), "Patient participation in the patient-provider interaction: the effects of patient question asking on the quality of interaction, satisfaction and compliance”, Health Education \& Behavior, Vol. 5 No. 4, pp. 281-315.

Schuster, L., Drennan, J. and Lings, I.N. (2013), “Consumer acceptance of m-wellbeing services: a social marketing perspective”, European Journal of Marketing, Vol. 47 No. 9, pp. 14391457.

Seiders, K., Flynn, A.G., Berry, L.L. and Haws, K.L. (2015), "Motivating customers to adhere to expert advice in professional services a medical service context”, Journal of Service Research, Vol. 18 No. 1, pp. 39-58.

Shaw, J. and Baker, M. (2004), “'Expert patient' - dream or nightmare?”, BMJ, Vol. 328 No. 7442, pp. 723-724.

Smith, M.S. and Wallston, K.A. (1992), “How to measure the value of health”, Health Education Research, Vol. 7 No. 1, pp. 129-135. 
Spanjol, J., Cui, A.S., Nakata, C., Sharp, L.K., Crawford, S.Y., Xiao, Y. and Watson-Manheim, M.B. (2015), "Co-production of prolonged, complex, and negative services: an examination of medication adherence in chronically ill individuals”, Journal of Service Research, Vol. 18 No. 3, pp. 284-302.

Spiggle, S. (1994), “Analysis and interpretation of qualitative data in consumer research”, Journal of Consumer Research, Vol. 21 No. 3, pp. 491-503.

Starfield, B. (2011), “Is patient-centered care the same as person-focused care?”, The Permanente Journal, Vol. 15 No. 2, pp. 63-69.

Stevenson, F.A. (2003), “General practitioners’ views on shared decision making: a qualitative analysis”, Patient Education and Counseling, Vol. 50 No. 3, pp. 291-293.

Stewart, M.A. (1984), "What is a successful doctor-patient interview? A study of interactions and outcomes”, Social Science \& Medicine, Vol. 19 No. 2, pp. 167-175.

Stewart, M., Brown, J.B., Donner, A., McWhinney, I.R., Oates, J., Weston, W.W. and Jordan, J. (2000), “The impact of patient-centered care on outcomes”, Journal of Family Practice, Vol. 49 No. 9, 796-804.

Stock, S., Drabik, A., Büscher, G., Graf, C., Ullrich, W., Gerber, A., Lauterbach, K.W. and Lüngen, M. (2010), "German diabetes management programs improve quality of care and curb costs”, Health Affairs, Vol. 29 No. 12, 2197-2205.

Strauss, A.L. (1987), Qualitative Analysis for Social Scientists, Cambridge University Press, Cambridge.

Street, R.L. and Voigt, B. (1997), "Patient participation in deciding breast cancer treatment and subsequent quality of life”, Medical Decision Making, Vol. 17 No. 3, pp. 298-306.

$\mathrm{Su}, \mathrm{X}$. and Zenios, S. (2004), "Patient choice in kidney allocation: the role of the queueing discipline”, Manufacturing \& Service Operations Management, Vol. 6 No. 4, pp. 280-301.

Sweeney, J.C., Danaher, T.S. and McColl-Kennedy, J.R. (2015), “Customer effort in value cocreation activities improving quality of life and behavioral intentions of health care customers”, Journal of Service Research, Vol. 18 No. 3, pp. 318-335.

Thomas, S., Bachman, D., Khuperkar, A. and Vadnerkar, G. (2014), “Dig deep: impacts and implications of rising out-of-pocket health care costs", Deloitte Centre for Health

Solutions, available at: http://www2.deloitte.com/us/en/pages/life-sciences-and-healthcare/articles/hidden-costs-of-health-care.html (accessed 26 November 2015).

Thompson, A.G.H. (2007), "The meaning of patient involvement and participation in health care consultations: a taxonomy”, Social Science \& Medicine, Vol. 64 No. 6, pp. 1297-1310.

Tian, K., Sautter, P., Fischer, D., Fischbach, S., Luna-Nevarez, C., Boberg, K., Kroger, K. and R. Vann (2014), “Transforming health care: Empowering therapeutic communities through technology-enhanced narratives”, Journal of Consumer Research, Vol. 41 No. 2, pp. 237260.

Topol, E. (2015), The Patient Will See You Now: The Future of Medicine is in Your Hands, Basic Books.

Tranfield, D., Denyer, D. and Smart, P. (2003), “Towards a methodology for developing evidence-informed management knowledge by means of systematic review”, British Journal of Management, Vol. 14 No. 3, pp. 207-222.

Tucker, A.L. (2004), “The impact of operational failures on hospital nurses and their patients”, Journal of Operations Management, Vol. 22 No. 2, pp. 151-169.

Vargo, S.L. and Lusch, R.F. (2004), “Evolving to a new dominant logic for marketing”, Journal of Marketing, Vol. 68 No. 1, pp.1-17. 
Vetter-Smith, M., LeMaster, J., Olsberg, J., Kruse, R., Day, T. and Mehr, D. (2012), “Providing diabetes self-management support in rural primary care clinics with nurse partners", Western Journal of Nursing Research, Vol. 34 No. 8, pp. 1023-1042.

Von Korff, M., Gruman, J., Schaefer, J., Curry, S.J. and Wagner, E.H. (1997), “Collaborative management of chronic illness”, Annals of Internal Medicine, Vol. 127 No. 12, pp. 10971102.

Voss, C., Perks, H., Sousa, R., Witell, L., \& Wünderlich, N. V. (2016), "Reflections on context in service research", Journal of Service Management, Vol. 27 No. 1, pp. 30-36.

Wagner, E.H., Bennett, S.M., Austin, B.T., Greene, S.M., Schaefer, J.K. and Vonkorff, M. (2005), "Finding common ground: patient-centeredness and evidence-based chronic illness care”, The Journal of Alternative and Complementary Medicine, Vol. 11 No. supplement 1, p. s-7.

Windrum, P. and García-Goñi, M. (2008), “A neo-Schumpeterian model of health services innovation”, Research Policy, Vol. 37 No. 4, pp. 649-672.

Wong, G., Greenhalgh, T., Westhorp, G., Buckingham, J. and Pawson, R. (2013), "RAMESES publication standards: meta-narrative reviews”, BMC Medicine, Vol. 11 No. 1, p. 20.

Wong, N. and King, T. (2008), "The cultural construction of risk understandings through illness narratives”, Journal of Consumer Research, Vol. 34 No. 5, pp. 579-594.

World Health Organization (2008), "WHO | The World Health report 2008 - primary health care (now more than ever)", WHO, available at: http://www.who.int/whr/2008/en/ (accessed 26 November 2015).

Yao, T., Zheng, Q. and Fan, X. (2015), “The impact of online social support on patients' quality of life and the moderating role of social exclusion”, Journal of Service Research, Vol. 18 No. 3, pp. 369-383.

Zainuddin, N., Russell-Bennett, R. and Previte, J. (2013), “The value of health and wellbeing: An empirical model of value creation in social marketing”, European Journal of Marketing, Vol. 47 No. 9, pp. 1504-1524.

Zayer, L.T., Otnes, C.C. and Fischer, E.M. (2015), "The nature and implications of consumers' experiential framings of failure in high-risk service contexts", Journal of Service Research, Vol. 18 No. 3, pp. 303-317. 
Table I. Roles of Health Care Customer and Professional in Each Practice Approach

$\begin{array}{lll}\text { Practice } & \text { Core elements } & \text { Role of the health care customer }\end{array}$

\section{approach}

Traditional

Model (1) a focus on the disease and not the person

(2) detecting deviations from "normal"

(3) the doctor as an authority and the decision-maker

Emphasis on the use of the physician's expert knowledg and skills to determine the patient's medical condition, medical tests required and treatments to be administered (Emanuel and Emanuel, 1992), with focus on the problem, not the person (Courtney et al., 1996).

Bio-

psychosocia

model

\section{Core elements:}

(1) social

(2) psychological and

(3) biomedical aspects in the treatment of patients

It offers a broader perspective to understanding suffering, disease and illness on multiple levels (Borrell-Carrió et al., 2004)

Patient

Centeredness

Core elements in the different approaches to Patient Centeredness relate to considering both the disease and the person, respecting the patients' values and needs, enhancing the patient-professional relationship and communication, coordinating care in a patient centered way, and involving patients in care and decision-making.

Focus on participation of patients, and patient and health professional relationships, and the context where care is delivered (Kitson et al. 2003).

\begin{tabular}{ll}
\hline Patient & The core element of Patient Participation is to activate and \\
Participation & increase the participation of the patient in different aspects of
\end{tabular} their care.

Patient Participation approach can be seen as distinct from Patient Centered Care in that it views the patient as being active in their own care and is viewed more from the patient's perspective, rather than the physician's perspective.

Patient Participation emphasizes the consumer's right to information, choice, voice and safety (Longtin et al., 2010)

\section{Role of the health care professional}

To comply with the doctor.

The patient in traditional medicine, to a large extent, has been viewed as a passive recipient of care (Wagner et al., 2005).

Early conceptualizations sees role of patient as a subject on whom doctors can observe, operate and practice their medicine (see Osler, 1901).

Essentially, patients were to show up to medical consultations, cooperate with the doctor (e.g., answering questions) and follow the instructions for treatment (see Morton, 1937). To engage in wide ranging dialogue with the clinician.

While the Biopsychosocial Model does not highlight the role of the patient, this model assumes that the patient openly shares information about him/herself, not only regarding their particular disease, but also about their psychological and social environment, such as information about their family and work situation and expresses feelings about his/her illness.

To be involved in decision-making and disease management.

Patient Centeredness is referred to by a number of terms, such as Patient Centered Care (PCC), Patient Centered Medicine, and Patient Centered communications, sometimes used interchangeably (Epstein et al., 2005).

Patient Centered Care (PCC) was popularized by the Picker Institute and the Institute of Medicine (Berghout et al., 2015).

\section{To participate in a range of consultation-related behaviors.}

An essential component of Patient Participation is the activation of patients in different aspects of their care. This includes sharing information and asking questions during consultations (Gallan et al., 2013; Roter, 1977), coming up with suggestions for treatment and engaging in decisionmaking (Gallan et al., 2013; Longtin et al., 2010). Gallan et al. 2013) also highlight the importance of patients having a positive attitude during consultations.
To be the patient's guardian.

By using their skills and knowledge to determine, doctors diagnose and make decisions about treatment and interventions (Emanuel and Emanuel, 1992).

Acting as the patient's guardian, the physician authoritatively determines what is best for the patient, whose main role is considered to be that of acquiescence.

\section{To foster wide ranging dialogue with the patient.}

The biopsychosocial approach problematizes the complexity of medicine and proposes that the clinician should not bypass the patient experience by placing greater reliance on technical procedures and measurements.

the most essential skills of the clinician "involve the ability to elicit accurately and then analyze the patient's verbal account of his illness experience” (Engel, 1977, p. 132).

To take a more whole person perspective.

In contrast to the TMM, in a Patient Centered Model, the physician emphasizes the "whole-person" perspective and respect for patients' values, needs, and preferences (Mead and Bower, 2000)

The professionals' role also includes coordinating care with the patient as central, informing and educating patients, showing emotional support, and involving patients in decision-making.

\section{behaviors.}

The health care professional's role is to encourage and facilitate participation (Longtin et al., 2010). This includes sharing power, and including patients in consultations about treatment decision-making and in the treatment plan. 


\begin{tabular}{|c|c|c|c|}
\hline $\begin{array}{l}\text { Patient } \\
\text { Empowerment }\end{array}$ & $\begin{array}{l}\text { Core elements: } \\
\text { (1) patients understanding their disease and its effects on their } \\
\text { body } \\
\text { (2) patients taking control and gaining confidence } \\
\text { (3) patients developing skills to solve problems and make } \\
\text { decisions. }\end{array}$ & $\begin{array}{l}\text { To take control. } \\
\text { Patients are viewed as active, in reading and learning about } \\
\text { their condition, engaging in relationships with health care } \\
\text { professionals, mobilizing needed resources and engaging in } \\
\text { lifestyle changes related to their disease (Gibson, 1991). }\end{array}$ & $\begin{array}{l}\text { To enable the patient to take control. } \\
\text { Professionals share control and power with the patients with } \\
\text { regard to decision-making, collaborating, educating and } \\
\text { empowering patients to support themselves in taking control } \\
\text { and responsibility (Gibson, 1991). }\end{array}$ \\
\hline & $\begin{array}{l}\text { Patient Empowerment has been defined as "a social process of } \\
\text { recognizing, promoting, and enhancing people's abilities to } \\
\text { meet their own needs, solve their own problems and mobilize } \\
\text { the necessary resources in order to control their lives" } \\
\text { (Gibson, 1991, p. 359). }\end{array}$ & $\begin{array}{l}\text { Another emphasized aspect of Patient Empowerment is the } \\
\text { importance of patients understanding, taking control and } \\
\text { having responsibility for their disease (Anderson, 1995; } \\
\text { Ouschan et al., 2000). }\end{array}$ & $\begin{array}{l}\text { Rather than doing things for the patient, their role is to help } \\
\text { the patient themselves in becoming confident in controlling } \\
\text { and managing their disease. }\end{array}$ \\
\hline $\begin{array}{l}\text { Shared } \\
\text { Decision- } \\
\text { Making (SDM) }\end{array}$ & $\begin{array}{l}\text { Core elements: } \\
\text { (1) sharing information and expertise } \\
\text { (2) negotiating and discussing options } \\
\text { (3) making medical decisions on mutual agreement between } \\
\text { patients and professionals. } \\
\text { A key distinctive feature of SDM is the mutual process, in } \\
\text { which both patients and professionals must be active and } \\
\text { involved. } \\
\text { However, even if patients' rights to be informed and to } \\
\text { participate in decision-making are well accepted, it is not } \\
\text { always well implemented (Stevenson, 2003), and SDM is } \\
\text { often positioned as a "middle ground" between paternalism } \\
\text { and full patient autonomy (Makoul and Clayman, 2006). }\end{array}$ & $\begin{array}{l}\text { To partner with the clinician in decision-making. } \\
\text { In SDM, ideally the patient is active during medical } \\
\text { consultations and engages in defining their preferred role in } \\
\text { decision-making, engages in a partnership with the clinician, } \\
\text { articulates health problems and expectations, communicates, } \\
\text { accesses and evaluates information, and negotiates and agrees } \\
\text { on an action plan (Frosch and Kaplan, 1999). }\end{array}$ & $\begin{array}{l}\text { To respect the patient's preferred role in decision-making. } \\
\text { To engage in SDM, the health care professional in turn must } \\
\text { be willing to establish a relationship with the patient and } \\
\text { take time to understand the patient's preferred role in } \\
\text { decision-making, sharing expertise and evidence, } \\
\text { identifying choices, responding to the patient's ideas and } \\
\text { concerns, and discussing options (Charles et al., 1997). } \\
\text { Accordingly, decisions on treatment should be made based } \\
\text { on mutual agreement. }\end{array}$ \\
\hline $\begin{array}{l}\text { Person-Centred } \\
\text { Care }\end{array}$ & $\begin{array}{l}\text { Core elements are: } \\
\text { (1) to consider the person seeking counseling is an expert on } \\
\text { him/her self } \\
\text { (2) to address the person's holistic and specific assets } \\
\text { including individual, social and contextual factors } \\
\text { (3) to place emphasis on the relationship and communication } \\
\text { between health care professionals (and others) and the health } \\
\text { care customer }\end{array}$ & $\begin{array}{l}\text { Patient as the expert on him/herself. } \\
\text { In this approach, the health care customer is viewed as an } \\
\text { individual person who is the expert on him/her self (Ekman } \\
\text { et al., 2011). This involves actively engaging the customer as } \\
\text { an expert in all parts of care including treatment and decision- } \\
\text { making and forming partnerships with professionals. }\end{array}$ & $\begin{array}{l}\text { Empower patient to be the expert on him/herself and } \\
\text { professional as expert on care. } \\
\text { The health care professional's role is to assist and } \\
\text { empower the individual in an authentic way to become } \\
\text { more expert, to find meaning in their existing situation and } \\
\text { plan for the future (McCormack, 2004). Start with the } \\
\text { person's own narrative and experience (Ekman et al., } \\
\text { 2011). }\end{array}$ \\
\hline $\begin{array}{l}\text { Collaborative } \\
\text { Care }\end{array}$ & $\begin{array}{l}\text { Core elements are: } \\
\text { (1) sharing of goals } \\
\text { (2) engaging in building relationships } \\
\text { (3)mobilizing resources outside the narrow patient- } \\
\text { professional dyad } \\
\text { The approach emphasizes patients' and health-care providers' } \\
\text { shared goals, sustained working relationships, mutual } \\
\text { understanding of roles and responsibilities. It goes beyond the } \\
\text { patient-health professional dyad to highlight the active role } \\
\text { that employers, community organizations, government, and } \\
\text { other customers play in improving health care outcomes (Von } \\
\text { Korff et al., 1997). As such it is,similar to multiple actors in a } \\
\text { service ecosystem (Lusch, 2011). }\end{array}$ & $\begin{array}{l}\text { As collaborator in health ecosystem. } \\
\text { The health care customer's role is viewed as collaboratively } \\
\text { defining problems with the health care professional, and } \\
\text { being involved in goal setting and in the planning of care } \\
\text { within a broader ecosystem (Courtney et al., 1996; Von } \\
\text { Korff et al., 1997). } \\
\text { The customers' role is conceptualized as an active and willing } \\
\text { participant in self-determination of problems and solutions. } \\
\text { The customer is active in learning, goal setting, and building } \\
\text { relationships with professionals, families, groups, and } \\
\text { coalitions of resources with the professional. }\end{array}$ & $\begin{array}{l}\text { As collaborator in the health ecosystem. } \\
\text { Instead of being an expert who solves problems and makes } \\
\text { decisions alone and separate from the customer, the } \\
\text { professional acts as a partner who does things with the } \\
\text { customer and others (Courtney et al., 1996). They act as } \\
\text { facilitators and enablers who share power and leadership, } \\
\text { and continuously negotiate goals, roles and responsibilities. } \\
\text { This facilitating and enabling is done while respecting } \\
\text { individual and cultural differences, collaboratively defining } \\
\text { problems and creating a continuum of self-management } \\
\text { training and support that guide and assist health behavior } \\
\text { changes (Von Korff et al., 1997). }\end{array}$ \\
\hline
\end{tabular}




\begin{tabular}{|c|c|c|c|}
\hline $\begin{array}{l}\text { Self-Managed } \\
\text { Care }\end{array}$ & $\begin{array}{l}\text { Core elements are: } \\
\text { (1) customers' management and monitoring of care } \\
\text { (2) involvement and responsibility in self-care and daily } \\
\text { decision-making } \\
\text { (3) changing lifestyle to fit one's condition. } \\
\text { Self-management refers to the "individual's ability to manage } \\
\text { the symptoms, treatment, physical and psychosocial } \\
\text { consequences and life style changes inherent in living with a } \\
\text { chronic condition" (Barlow et al., 2002, p. 177). }\end{array}$ & $\begin{array}{l}\text { Self manager. } \\
\text { Core patient self-management skills and activities include } \\
\text { patients engaging in problem solving, decision-making, } \\
\text { resource utilization, sharing information, and forming } \\
\text { patient/health care provider partnerships (Lorig and Holman, } \\
\text { 2003). }\end{array}$ & $\begin{array}{l}\text { Facilitator of patient's self-management. } \\
\text { Health care professionals have a role in educating the } \\
\text { patient about their disease and teaching self-care skills, } \\
\text { forming relationships (with patients, families, communities), } \\
\text { and in facilitating self-care and peer education (Lorig and } \\
\text { Holman, 2003). }\end{array}$ \\
\hline $\begin{array}{l}\text { Health Care } \\
\text { Value } \\
\text { Co-creation }\end{array}$ & $\begin{array}{l}\text { Core elements are: } \\
\text { (1) the customer is an active co-creator of value and a } \\
\text { collaborator in care, albeit to varying extents, depending on } \\
\text { how the customer perceives the benefits (that is, perceived } \\
\text { value) } \\
\text { (2) health care customers will co-create value in differing } \\
\text { ways } \\
\text { (3) integrating different sets of resources, with potentially a } \\
\text { wide range of collaborators. For example, some health care } \\
\text { customers may see value in engaging in many and varied } \\
\text { activities and interactions, while others would rather engage in } \\
\text { fewer activities and interactions to co-create value. } \\
\text { (McColl-Kennedy et al., 2012). }\end{array}$ & $\begin{array}{l}\text { Active co-creator of value. } \\
\text { Patients are seen as active co-creators of value with } \\
\text { professionals and other actors integrating resources in the } \\
\text { customer's service network. This may include being active in } \\
\text { the production of care, learning and sharing information, being } \\
\text { involved in diagnosis, disease and recovery, regulating } \\
\text { emotions, forming relations and mobilizing resources. } \\
\text { Importantly, the constellation of activities and interactions } \\
\text { vary between health care customers based on what is of value } \\
\text { to them. }\end{array}$ & $\begin{array}{l}\text { To work with the customer and others in the ecosystem. } \\
\text { The role of the health care professional is to work with the } \\
\text { health care customers, and potentially with others, } \\
\text { including other health care providers such as allied } \\
\text { health care professionals in the customer's service } \\
\text { network to importantly realize benefit as defined by the } \\
\text { customer. }\end{array}$ \\
\hline
\end{tabular}


Table II. Established effects of changing health care customer roles in the key practice approaches

\section{Traditional medical model}

No identified relationships.

\section{Biopsychosocial model}

No identified relationships.

\section{Patient centeredness}

- $\quad$ Patient centered practice is shown to improve health status and increase the efficiency of care by reducing diagnostic tests and referrals (Stewart et al., 2000). [Observational cohort study, primary care patients $\mathrm{n}=315$ ]

- $\quad$ Consultations in which clinician demonstrated a high frequency of patient-centered behavior were related to significantly higher reported compliance and was also shown to affect drug use and patient satisfaction (Stewart, 1984). [Observations and interviews, primary care patients $n=140]$

- $\quad$ More patient centered approaches in routine consultations were shown to be associated with higher indicators of patient satisfaction in patients with diabetes (Moran et al., 2008). [Cross-sectional observations, diabetes patients $n=44$ ]

- An education program in patient centered care for practitioners led to patients with newly diagnosed diabetes reporting better communication with doctors, greater well-being, and greater treatment satisfaction (Kinmonth et al., 1998) [Randomized controlled trial, diabetes patients $n=610]$

\section{Patient participation}

- Greater patient participation in consultations has been shown to affect patients' knowledge, satisfaction and motor functioning (Greenfield et al., 1985). [Randomized controlled trial, ulcer disease patients n=78]

- Interventions that promote patient participation in care changes patient behavior, improve blood sugar control, and decreases functional limitations in patients with diabetes (Greenfield et al., 1988). [Randomized controlled trial, diabetes patients $\mathrm{n}=59$ ]

\section{Patient empowerment}

- $\quad$ Programs for patient empowerment have been shown to affect psychosocial aspects as well as improving glucose control in diabetes patients (Anderson et al., 1995). [Randomized controlled trial, $\mathrm{n}=64$ ]

\section{Shared decision-making}

- $\quad$ Greater patient participation in decision-making is shown to lead to higher patient satisfaction (Loh et al., 2007). [Randomized controlled trial, patients with depression $n=405$ ]

- Involvement in decision-making is shown to lead to a decrease of decisional conflict between patients and physician and a decrease of stress levels in people living with HIV (Kremer et al., 2007). [Cross-sectional survey, HIV patients n=79]

- $\quad$ Shared decision-making can increase health-related quality of life and decrease work disability in adults living with asthma (Adams et al., 2001). [Cross-sectional observational study, asthma patients $n=128]$

- Involvement in decision-making was shown to result in more effective pain control in the case of chronic pain patients (Manias and Williams 2008). [Observations and interviews, renal patients $n=53$ ]

- $\quad$ Patients who believed they were more responsible for treatment decisions and believed they had more choice of treatment reported higher levels of quality of life than the patients who perceived themselves to have less decision control (Street and Voigt, 1997). [Longitudinal study, cancer patients $n=60$ ]

\section{Collaborative care}

- $\quad$ Collaborative Care is more effective than standard care in improving depression outcomes in the short and longer terms among patients (Gilbody et al., 2006). [Meta-analysis of randomized controlled trials $\mathrm{n}=37$ ]

\section{Person-centered care}

- $\quad$ A fully implemented Person-Centered Care approach was shown to shorten hospital stay and maintain functional performance in hospitalized patients (Ekman et al., 2012). [Randomized controlled trial, chronic heart failure patients n=248]

\section{Self-management}

- $\quad$ Promoting self-management is shown to reduce the number of health care visits in chronic disease and reduce cost (Lorig et al., 2001) [Longitudinal, randomized controlled trial, patient with chronic diseases $\mathrm{n}=831$ ]

- $\quad$ Patient education and self-management was shown to reduce the need for GP visits, increase the patients' independence and reduce the number of days off work in relation to asthmatic diseases (Gallefoss and Bakke 2000). [Randomized controlled trial, asthmatic patients $\mathrm{n}=140]$

- $\quad$ Self-management programs increased compliance, improved functional capacity, and reduced hospitalization rate for heart failure patients (Gotsman et al., 2011). [Longitudinal study of clinical outcomes, heart failure patients $\mathrm{n}=6618$ ]

- $\quad$ Self-management was shown to increase patient satisfaction for patients with long term diseases (Lorig et al., 2008). [Prospective longitudinal study, long term diseases $\mathrm{n}=443$ ]

- $\quad$ Nurse led self-management programs was shown to improve health outcomes for patients with diabetes (Vetter-Smith et al., 2012). [Multiple case-studies, diabetes patients]

- $\quad$ Self-management programs were shown to significantly lower overall mortality and drug and hospital costs in relation to diabetes patients (Stock et al., 2010). [Longitudinal study, cancer and pulmonary disease patients $n=91,696$ ]

- When customers perceive causality for making decisions there is more negative emotion than when the choice is made externally regarding "tragic choices"(Botti et al., 2009). [Interviews, parents to prenatal babies n=19, experiments, students n=177, 146, 145] 


\section{Health care value co-creation}

- Active engagement in various value creating activities and interactions are associated with a higher quality of life (McColl-Kennedy et al., 2012) [In-depth interviews, cancer patients $\mathrm{n}=20$ ] and greater well-being (McColl-Kennedy et al. 2016), [diary study $\mathrm{n}=20$ and six separate survey samples, ongoing illnesses $n=251$, ongoing illnesses $n=250$, cardiovascular $n=257$, musculoskeletal $n=138$, and psychological $n=235$ : total $=1151]$

- $\quad$ Customer effort in value co-creation activities effects satisfaction with the service. Value co-creation was also shown to lead to higher levels of quality of life (Sweeney et al., 2015). [Survey, cancer, heart and diabetes $n=1008$ ]

- Active cocreation of health care patients using digital entertainment to bring about a more human face to health care focusing on "preventative, holistic, cocreated community-supported endeavors" (Tian et al., 2014). [Ethnographic, participants with type 2 diabetes $\mathrm{n}=35$ ] 
Table III.

A research agenda for health care service research

\section{Managing co-creative practices}

a. What are the underlying mechanisms that link health care customers and organizations?

b. How should health care organizations be re-designed to better support co-creative practice principles?

c. How should new practices be embedded to enable customers and professionals to better co-create value and co-produce service(s)?

\section{Better understanding of roles during value co-creation}

a. How are the respective roles of health care customers and the various other health professionals defined during value co-creation?

b. What processes, tools, and business practices are useful in defining, motivating, and managing health care customer and employee roles?

c. How should the respective roles of each player be conveyed to the other parties involved in value cocreation?

d. How should the various activities and interactions of the players be integrated to provide a seamless health care experience?

\section{Co-production models for innovation and development}

a. In what ways can health care customers contribute to the design of new products and services?

b. How can technology better enable health service to continue to be provided, co-produced and coordinated in the patient's home?

\section{The effects of changing health care customer roles}

a. How can we better understand the effect of the changing role of the customer at the various touchpoints in the customer journey?

b. What metrics can be used to capture shared decision-making (choices) across touchpoints in the customer journey and their effects on outcomes?

\section{Dysfunctional health care customer behavior}

a. What motivates health care customers to lie/not disclose important medical information required in treatments?

b. Why do some health care customers sabotage treatments?

c. Why do some health care customers refuse "healthy" choices?

6. Use of technology to enhance the health care experience

a. How can technology be used to assist in decision-making on treatment plans to minimize errors?

b. What is the impact of wearing tracking devices on health care customer behavior?

c. What are the ethical considerations that need to be taken into account by health professionals?

d. Does the technology enhance or hinder compliance on the part of the health care customer? Why?

\section{Conditions underlying negative services}

a. What are the characteristics of patients who are motivated to take on high levels of responsibility?

b. What kinds of emotional support do patients need when they are involved in decision-making? 


\section{Appendix 1}

\section{Key practice approaches in health care: illustrative examples}

\begin{tabular}{|c|c|c|c|}
\hline \multicolumn{4}{|c|}{ Traditional medical model } \\
\hline Author(s) & Conceptualization & Discipline & Overall contribution \\
\hline Osler (1901) & $\begin{array}{l}\text { [Teaching the art of medicine] "Ask a practitioner of twenty years standing how he has become proficient in his } \\
\text { art, he will reply, by constant contact with disease" (p. 1673).... "He questions, repeats the answers [from the } \\
\text { patient] and makes the examination. He is taught to use his senses in a simple and orderly manner. The seeing eye } \\
\text { and the feeling finger are products of long training. How to see and what to see, how to touch and what to touch." } \\
\text { (p. 1674) }\end{array}$ & Medicine & $\begin{array}{l}\text { One of the first articles to recognize that the art of medicine } \\
\text { starts with observations of the patient }\end{array}$ \\
\hline $\begin{array}{l}\text { Emanuel and } \\
\text { Emanuel } \\
\text { (1992) }\end{array}$ & $\begin{array}{l}\text { [Paternalistic model] "The physician-patient interaction ensures that patients receive the interventions that best } \\
\text { promote their health and well-being. To this end, clinicians use their skills to determine the patient's medical } \\
\text { condition and his or her stage in the disease process and to identify the medical tests and treatments most likely to } \\
\text { restore the patient's health or ameliorate pain. Then the physician presents the patient with selected information } \\
\text { that will encourage the patient to consent to the intervention the physician considers best. At the extreme, the } \\
\text { physician authoritatively informs the patient when the intervention will be initiated." (p. 2221) }\end{array}$ & Medicine & $\begin{array}{l}\text { Illustrated four types of communication styles in the medical } \\
\text { encounter }\end{array}$ \\
\hline \multicolumn{4}{|c|}{ Biopsychsocial model } \\
\hline Engel (1977) & $\begin{array}{l}\text { [Biopsychosocial model] "A medical model that takes into account the patient, the social context in which he } \\
\text { lives, and the complementary system devised by society to deal with the disruptive effects of illness, that is, the } \\
\text { physician role and the health care system." (p. 132] }\end{array}$ & Psychiatry & $\begin{array}{l}\text { Expands the Traditional Medical Model to include individual } \\
\text { experience, social context and surrounding systems in patient } \\
\text { care }\end{array}$ \\
\hline $\begin{array}{l}\text { Gatchel et al. } \\
\text { (2007) }\end{array}$ & $\begin{array}{l}\text { [Biopsychosocial model in chronic pain] "The biopsychosocial model focuses on both disease and illness, with } \\
\text { illness being viewed as the complex interaction of biological, psychological, and social factors [...] disease is } \\
\text { defined as an objective biological event involving the disruption of specific body structures or organ systems } \\
\text { caused by either anatomical, pathological, or physiological changes. In contrast, illness refers to a subjective } \\
\text { experience or self-attribution that a disease is present. Thus, illness refers to how a sick person and members of } \\
\text { his or her family live with, and respond to, symptoms of disability.” (p. 582) }\end{array}$ & Psychology & $\begin{array}{l}\text { Emphasizes the influence of psychological and social factors } \\
\text { on health and illness: goes beyond the patient-physician dyad } \\
\text { by including family }\end{array}$ \\
\hline \multicolumn{4}{|c|}{ Patient centeredness } \\
\hline $\begin{array}{l}\text { Gerteis et al. } \\
\text { (1993) }\end{array}$ & $\begin{array}{l}\text { [Patient centered care (PCC)] While a clear definition is lacking (Rathert et al. 2012), there is some agreement on } \\
\text { the following key dimensions of PCC comprising: (1) respect for patients' values, preferences, and expressed } \\
\text { needs; (2) coordination and integration of care; (3) information, communication, and education; (4) physical } \\
\text { comfort; (5) emotional support; (6) involvement of family and friends; (7) transition and continuity; and (8) } \\
\text { access to care and services. }\end{array}$ & Nursing & $\begin{array}{l}\text { Provides a comprehensive framework and dimensions of } \\
\text { Patient centered care (PCC) }\end{array}$ \\
\hline $\begin{array}{l}\text { Mead and } \\
\text { Bower } \\
\text { (2000) }\end{array}$ & $\begin{array}{l}\text { [Patient Centeredness] Five conceptual dimensions: Biopsychosocial perspective (broadening the scope of } \\
\text { medicine from organic disease to a wider range of dysfunctional states): "patient-as-person”" (understanding the } \\
\text { individual’s experience of illness): sharing power and responsibility (encouraging significantly greater patient } \\
\text { involvement in care): therapeutic alliance (far greater priority to the personal relationship between doctor and } \\
\text { patient): and "doctor-as/person” (regards the personal qualities of the doctor)..."Once passive recipients of } \\
\text { medical care, patients are increasingly regarded as active consumers' (and potential critics) with the right to } \\
\text { certain standards of service, including the right to full information, to be treated with respect and to be actively } \\
\text { involved in decision-making about treatment.” (p. 1090) }\end{array}$ & $\begin{array}{l}\text { Social } \\
\text { science and } \\
\text { health }\end{array}$ & $\begin{array}{l}\text { Broadens the scope of Patient Centeredness by including new } \\
\text { dimensions that emphasizes patient involvement, the physician } \\
\text {-patient relationship and the personal qualities of the physician }\end{array}$ \\
\hline \multicolumn{4}{|c|}{ Patient participation } \\
\hline Roter (1977) & $\begin{array}{l}\text { [Patient participation in medical consultations] "Essential to the movement is a conception of the patient and the } \\
\text { consumer as active in their own health care. Patient discontent with physician-centered care and physician } \\
\text { dominated therapeutic relationships may be seen as a rejection of the long-standing patient role." (p. 282) }\end{array}$ & $\begin{array}{l}\text { Health } \\
\text { education }\end{array}$ & $\begin{array}{l}\text { One of the first empirical studies to acknowledge and } \\
\text { investigate patient participation (asking questions) in } \\
\text { medical consultations }\end{array}$ \\
\hline $\begin{array}{l}\text { Gallan et al.. } \\
\text { (2013) }\end{array}$ & $\begin{array}{l}\text { [Patient participation] "The extent to which customers share information, provide suggestions, and engage in } \\
\text { shared decision-making - reflects customer effort in co-producing a service" (p. } 340)\end{array}$ & Marketing & $\begin{array}{l}\text { Demonstrates a connection between patient positivity and } \\
\text { patient participation and satisfaction with care. }\end{array}$ \\
\hline
\end{tabular}


Charles et al. [Shared decision-making] Key characteristics of shared decision-making (1) that at least two participants,

(1997) physician and patient be involved; (2) that both parties share information; (3) that both parties take steps to build

a consensus about the preferred treatment, and; (4) that an agreement is reached on the treatment to implement.

Frosch and [Shared decision-making] "Shared decision-making is a process by which doctor and patient considers available

Kaplan information about the medical problem in question, including treatment options and consequences, and then

(1999) consider how these fit with the patient's preferences for health states and

[Patient Empowerment] “A social process of recognizing, promoting, and enhancing people's abilities to meet

(1991)

Ouschan et $\quad$ (Pa)

[Patient Empowerment] "In the context of medical consultations, we propose Patient Empowerment is reflected through the following three dimensions (i) patients' perceived control over the illness; (ii) participation in medical decision-making processes; and (iii) the patient's perception of education that takes place during medica encounters." (p. 106)

\section{Person-centered care}

\begin{tabular}{|c|c|c|c|}
\hline \multicolumn{4}{|c|}{ Person-centered care } \\
\hline $\begin{array}{l}\text { Kitwood } \\
(1997)\end{array}$ & $\begin{array}{l}\text { [Person centeredness] “... a standing or status that is bestowed upon one human being, by others, in the context } \\
\text { of relationship and social being. It implies recognition, respect and trust.” (p. 8) }\end{array}$ & $\begin{array}{l}\text { Clinical } \\
\text { psychology }\end{array}$ & $\begin{array}{l}\text { One of the first to define and discuss the concept of Person } \\
\text { Centeredness in relation to health care. }\end{array}$ \\
\hline $\begin{array}{l}\text { Ekman et al. } \\
\text { (2011) }\end{array}$ & $\begin{array}{l}\text { [Person-Centered Care] "Highlights the importance of knowing the person behind the patient - as a human being } \\
\text { with reason, will, feelings, and needs - in order to engage the person as an active partner in his/her care and } \\
\text { treatment" (p. 249) }\end{array}$ & Nursing & $\begin{array}{l}\text { Provides guidelines on how to apply Person-Centered Care } \\
\text { in daily clinical practice }\end{array}$ \\
\hline \multicolumn{4}{|c|}{ Collaborative care } \\
\hline $\begin{array}{l}\text { Von Korff et } \\
\text { al. (1997) }\end{array}$ & $\begin{array}{l}\text { [Collaborative management] "Collaborative management is care that strengthens and supports self-care in } \\
\text { chronic illness while assuring that effective medical, preventive, and health maintenance interventions take } \\
\text { place." (p. 1097)...Essential elements of collaborative management are; 1) collaborative definition of problems, } \\
\text { in which patient-defined problems are identified along with medical problems diagnosed by clinician; 2) } \\
\text { targeting, goal setting, and planning 3) creation of a continuum of self-management training and support services } \\
\text { 4) active and sustained follow-up }\end{array}$ & Medicine & $\begin{array}{l}\text { Presents a comprehensive model for Collaborative Care } \\
\text { where the patient works in collaboration with health-care } \\
\text { providers }\end{array}$ \\
\hline \multicolumn{4}{|c|}{ Self-managed care } \\
\hline $\begin{array}{l}\text { Lorig and } \\
\text { Holman } \\
\text { (2003) }\end{array}$ & $\begin{array}{l}\text { [Self-management] The day-to-day decisions and activities engaged in by patients with the help of family and } \\
\text { friends to live with and control their illnesses. }\end{array}$ & $\begin{array}{l}\text { Health care } \\
\text { administration }\end{array}$ & $\begin{array}{l}\text { Provides a definition and operationalization of self- } \\
\text { management that goes beyond the professional-patient } \\
\text { dyad to include peers, family and communities }\end{array}$ \\
\hline $\begin{array}{l}\text { Shaw and } \\
\text { Baker (2004) }\end{array}$ & $\begin{array}{l}\text { [The expert patient] “....are those who can manage their own illnesses and conditions by developing knowledge } \\
\text { relevant to maintaining health and countering illness” (p. } 723 \text { )..."The minority of patients who have the resources } \\
\text { to find out about their illness and want to take an active part in managing their own care are to be welcomed as } \\
\text { allies and partners.” (p. 724) }\end{array}$ & Medicine & Introduces the notion of expert patients. \\
\hline \multicolumn{4}{|c|}{ Health care value co-creation } \\
\hline $\begin{array}{l}\text { McColl- } \\
\text { Kennedy et } \\
\text { al. (2012) }\end{array}$ & $\begin{array}{l}\text { Health care customer is the "primary resource integrator in the co-creation of their health care management.” } \\
\text {..."Customer value co-creation activities are activities that individuals carry out with others integrating resources } \\
\text { from the focal firm, other market-facing or public sources, private sources and through self-activities using } \\
\text { personal sources. (p. 8) }\end{array}$ & Service research & $\begin{array}{l}\text { The first empirical study that explores health care } \\
\text { customers co-creation of value and uncovers a typology of } \\
\text { Customer Value Co-creation Practice Styles (CVCPS) }\end{array}$ \\
\hline $\begin{array}{l}\text { Rosenbaum } \\
\text { and } \\
\text { Smallwood } \\
\text { (2013) }\end{array}$ & $\begin{array}{l}\text { "These centers permit people affected by cancer to momentarily escape from medical settings and their homes, } \\
\text { which are often laden with cancer-related equipment and medicines, to idyllic home-like settings, or } \\
\text { servicescapes, with "cancer friends" “(p. 473) }\end{array}$ & Service research & $\begin{array}{l}\text { Illustrates the importance of activity programming at } \\
\text { cancer resource centers in their members (patients) life. }\end{array}$ \\
\hline
\end{tabular}

Social science Highlights the importance of the patients contributions and

and health rights in medical decision-making

Preventive Provides an summary and analysis on the research of SDM medicine and puts out directions for the future
Nursing

Health

marketing

\section{of Patient Empowerment.}

Provides dimensions for Patient Empowerment and suggests that patient control, patient education and patient participation must be considered simultaneously 


\section{Author bios}

Janet McColl-Kennedy is Professor of Marketing in the UQ Business School, The University of Queensland, Brisbane Australia. She is recognized internationally as a leading researcher in Service Science. Her research interests include customer experience, service recovery, customer complaining behavior, customer rage and customer value co-creation. She has a particular interest in health service. She has published articles in Journal of Retailing, Journal of the Academy of Marketing Science, Leadership Quarterly, Journal of Service Research, Journal of Service Management, California Management Review, Psychology \& Marketing, Journal of Business Research, Journal of Marketing Management and Industrial Marketing Management. Email: j.mccoll-kennedy@business.uq.edu.au

Hannah Snyder is a Lecturer in the UQ Business School at the University of Queensland, Brisbane, Australia. She holds a PhD from the Department of Logistics and Quality at Linköping University, Linköping, Sweden. Her research interests are in service innovation, customer creativity, service innovation and customer value co-creation. She has particular interests in health care. Her work is published in the Journal of Business Research and the International Journal of Nursing Studies. Email: h.snyder@business.uq.edu.au

Mattias Elg is Professor of Quality Technology and Management, Linköping University, Sweden. His research is concerned with conditions and models to drive service development in organizations in both the private and public sectors. His research interests include customer co-creation, sustainable development in organizations, organizational change and performance measurement practice. He has published articles in BMC Health Services Research, International Journal of Operations and Production Management, Total Quality Management \& Business Excellence, International Journal of Productivity \& Performance Management, and International Journal of Health Care Quality Assurance.

Email: mattias.elg@liu.se

Lars Witell is a Professor at the CTF Service Research Center at Karlstad University, Sweden. He also holds a position as Professor Business Administration at Linköping University, Sweden. He conducts research on service innovation, customer co-creation and service infusion in manufacturing firms. He has published about 50 papers in scholarly journals such as Journal of Service Research, Journal of Service Management and Industrial Marketing Management, as well as in the popular press, such as The Wall Street Journal.

Email: lars.witell@liu.se

Anu Helkkula is Research Services Manager and PhD Programme Director at the Hanken School of Economics in Helsinki, Finland and an Adjunct Professor at University of Naples, Federico II. Her primary research interests include service and value experience, value creating practices, co-creation of value, healthcare service, user-based service innovation and development of innovation practices. She has worked for 20 years in service management and development positions. Her research has appeared in the Journal of Service Research, Journal of Service Management, Qualitative Market Research, International Journal of Pharmaceutical and Health Care Marketing, Journal of Customer Behaviour and Journal of Applied Management and Entrepreneurship. Email: anu.helkkula@hanken.fi 
Suellen Hogan is a Researcher and Lecturer at the University of Queensland (UQ). She holds a PhD and Bachelor of Business Management (Honours $1^{\text {st }}$ Class) from UQ. Her research interests include professional services, healthcare, value co-creation, organizational innovation and creativity, organizational culture, consumer goal preferences and multiparty consumption choices, and structural choice modelling. Her work is published in Industrial Marketing Management, and Journal of Business Research. Suellen has managed several large research projects and has extensive industry experience within the Health Care, Legal, Retail, Hospitality and Executive Recruitment industries.

Email: s.hogan@business.uq.edu.au

Laurel Anderson is an Associate Professor at Arizona State University. Her research interests include alternative views of services and

Transformative Service Research, social justice, value-laden services, community action research, space as public good, going between cultural worlds, self-socialization of teens, health organizations and consumer-centricity. She is published in Journal of Consumer Research, Journal of Service Research, Journal of Business Research, Journal of Public Policy \& Marketing, and Journal of Advertising. Email:

laurel.anderson@asu.edu 